\title{
Revision of the New World Panthea Hübner (Lepidoptera, Noctuidae) with descriptions of 5 new species and 2 new subspecies
}

\author{
Gary G. Anweiler \\ E.H. Strickland Entomological Museum, 218 Earth Sciences Building, Department of Biological Sciences, \\ University of Alberta, Edmonton, Alberta, Canada, T6G 2 E9 \\ urn:lsid:zoobank.org:author:87B63195-32B4-4FAF-8732-54242BF1FAA9 \\ Corresponding author: Gary G. Anweiler (gganweiler@shaw.ca) \\ Academic editor: B. Christian Schmidt | Received 12 January 2009 | Accepted 23 April 2009 | Published 12 May 2009 \\ urn:lsid:zoobank.org:pub:20B00870-7416-4583-ADE0-4302E5571B66 \\ Citation: Anweiler GG (2009) Revision of the New World Panthea Hübner (Lepidoptera, Noctuidae) with descriptions \\ of 5 new species and 2 new subspecies. In: Schmidt BC, Lafontaine JD (Eds) Contributions to the Systematics of New \\ World Macro-Moths. ZooKeys 9: 97-134. doi: 10.3897/zookeys.9.157
}

\begin{abstract}
The New World species of Panthea Hübner are revised. Five species and two subspecies are described as new: Panthea apanthea sp. n., Panthea reducta sp. n., Panthea greyi sp. n., Panthea judyae sp. n., Panthea guatemala sp. n., Panthea furcilla australis ssp. n., and Panthea acronyctoides nigra ssp. $\mathbf{n}$. Lectotypes are designated for Panthea leucomelana Morrison and Panthea furcilla (Packard), and a neotype is designated for Platycerura gigantea French. Panthea pallescens McDunnough, syn. n. is synonymized with $P$. furcilla (Packard), $P$. acronyctoides albosuffusa McDunnough, syn. $\mathbf{n}$. is synonymized with $P$. acronyctoides acronyctoides Walker, $P$. portlandia Grote, syn. n., $P$. portlandia suffusa McDunnough, syn. n., and $P$. angelica (Dyar), syn. n. are all synonymized with $P$. virginarius (Grote). Adults of all New World Panthea are illustrated in color, and black and white illustrations of the genitalia of both sexes are provided where known. A key to adults of both sexes and dot maps showing distribution for all species are provided.
\end{abstract}

\section{Keywords}

Pantheinae, lectotype, neotype, Guatemala, Mexico, Dominican Republic

\section{Introduction}

Panthea Hübner, 1820 (Noctuidae, Pantheinae) is Holarctic, with six Old World and nine New World species (Poole 1989; Hodges et al. 1983; Thony 1996). In the eastern

Copyright Gary G. Anweiler. This is an open access article distributed under the terms of the Creative Commons Attribution License, which permits unrestricted use, distribution, and reproduction in any medium, provided the original author and source are credited. 
hemisphere Panthea occur south to Southeast Asia, in the western hemisphere south to Central America and the Caribbean. Panthea is most diverse in the American Southwest, and all species for which there are habitat data are denizens of coniferous woodlands.

Panthea are placed in the Pantheinae, traditionally treated as a subfamily of the Noctuidae (Poole 1989; Franclemont and Todd 1983). Kitching and Rawlins (1999) elevated Pantheinae to family status, but Lafontaine and Fibiger (2006) revised them back to subfamily status in their expanded concept of Noctuidae, which is followed here.

Panthea are robust, medium-sized (approximately $3-6 \mathrm{~cm}$ wingspan) noctuid moths with a forewing pattern of five black lines crossing a white or gray ground. The extent of sexual dimorphism varies in expression among species, and where it occurs it is expressed as females being larger and darker than males. Male antennae are bipectinate, female antennae simple. The eyes are hairy, and the mouthparts of both sexes are greatly reduced and apparently non-functional. The male uncus and female sterigma are greatly modified and provide excellent characters for identification at the species-group and species levels. Several taxa have a variety of forms, with some populations of one species occurring in a form that resembles a form of another species more than other populations of the same species. As a result a number of taxa have been overlooked, others have been described more than once, and misidentifications are frequent in museum collections and in the literature (McDunnough 1942; Bowman 1951; Crumb 1956; Prentice 1962). Melanism is frequent in some eastern populations of nominate $P$. furcilla (Packard), and has also been reported for $P$. furcilla australis and some eastern populations of nominate $P$. acronyctoides (Walker) (Klots 1964; Klots 1966; Klots 1968; Brou pers. comm. 2008; Anweiler, unpublished data). This phenomenon appears to be more or less restricted to the eastern United States and is extremely rare or non-existent in other Panthea populations. The hairy larvae of all species, so far as is known, feed only on needles of conifers (Pinaceae) and in particular pines (Smith and Dyar 1898; Crumb 1956; Prentice 1962; Duncan 2006; Anweiler unpublished data).

The purpose of this paper is to revise the New World Panthea, describe new taxa, and provide illustrations, keys and distribution maps that will assist in identifying these interesting moths. Life history and habitat information is briefly summarized when available.

\section{Materials and methods}

Procedures for dissecting and preparing genitalia and terminology for wing markings follows that of Lafontaine (1987). Terminology for genitalic structures follows Lafontaine (2004).

Specimens or photographs of specimens were obtained from the following institutional collections and individuals; abbreviations used are as follows:

BMNH The Natural History Museum (formerly British Museum [Natural History]), London, United Kingdom. 
CNC Canadian National Collection of Insects, Arachnids and Nematodes, Ottawa, Ontario, Canada.

CSU Colorado State University, Fort Collins, Colorado, USA.

JKA personal collection of James Adams Dalton, Georgia, USA.

JTT personal collection of Jim Troubridge, Selkirk, Ontario, Canada.

LACM Los Angeles County Museum of Natural History, Los Angeles, California, USA.

MCZ Museum of Comparative Zoology, Cambridge, Massachusetts, USA.

MSU Michigan State University, Lansing, Michigan, USA.

NYSM New York State Museum, Albany, New York, USA.

RHL personal collection of Ron Leuschner, Los Angeles, California, USA.

RMB personal collection of Richard M. Brown, Stockton, California, USA.

UASM University of Alberta Strickland Entomological Museum, Edmonton, Alberta, Canada.

USNM National Museum of Natural History (formerly United States National Museum), Washington, D.C., USA.

\section{Panthea Hübner, [1820]}

Type species: Phalaena coenobita Esper.

Elatina Duponchel, [1845]. Type species: Phalaena coenobita Esper [extralimital]. Audela Walker, 1861. Type species: Audela acronyctoides Walker. Platycerura Packard, 1864. Type species: Platycerura furcilla Packard.

Diphthera Hampson, 1913, not Hübner, [1809]. Type species: Phalaena coenobita Esper [extralimital].

Diagnosis. The genus Panthea is characterized by a combination of characters including a dorsal forewing with a white or gray ground and a complete pattern of five black cross lines with the normal spots (reniform, orbicular and claviform) obsolete or nearly so. Male antennae are bipectinate and both sexes have greatly reduced apparently non-functional mouthparts. Male genitalia have simple heavily sclerotized valves with a well-developed clasper, a laterally compressed uncus with a high crown, triangular in cross-section and in lateral profile resembling a bird's head with beak, and a simple vesica armed with 1-3 large sclerotized cornuti. Females have a well-developed or massive sclerotized sterigma and a simple oval or oblong bursa copulatrix, lacking both appendices and signa.

Description. The genus Panthea is described and illustrated in detail in Smith and Dyar (1898). Head - broad, retracted; frons flat; eyes widely separated; ocelli small, concealed; proboscis greatly reduced, short, weak, apparently non-functional; palps small, slender, hardly extending to front; antenna bipectinate in male, simple in female; eyes hairy, without lashes. Thorax - quadrate, wider than long, with smooth hairy somewhat loose vesiture; legs short, stout, all similar in size, clothed with long loose hair; unarmed except for short, weak spurs; tarsal claws weak. Dorsal forewing 
- broadly triangular, outer margin oblique, with apex produced so costa is about $2 \times$ length of inner margin, clothed with a mixture of dark-gray or brownish-black and white scales, generally appearing gray; five black transverse lines; spots obsolete in most species, reniform and/or orbicular spot a small patch or bar of dark scales in a few species. Dorsal hindwing - usually lighter in color than forewing, poorly marked with several diffuse gray bands, or entirely gray in some forms. Abdomen - cylindrical, plump, longer in female, without tufts, clothed in short, stiff hair. Male genitalia valve simple but robust, heavily sclerotized with prominent erect clasper at distal end of sacculus; tegumen with a pair of large ear-like subuncal lobes; uncus highly modified, laterally compressed with high rounded crown sloping down and tapering to a narrow terminus; aedeagus cylindrical, slightly expanded at terminus in some species; vesica a membranous sac, armed with 1-3 large sclerotized cornuti in all but one species. Female genitalia - sterigma in all but one species well-developed, massively sclerotized in $P$. judyae group; ductus bursae variable in size and proportions, sclerotized or partially sclerotized in most species, usually folded or twisted and with a thickened wall; corpus bursae a simple translucent oval or oblong sac, with thick-walled upper and thin-walled lower section in $P$. furcilla group; signa absent.

\section{Key to the New World Panthea}

$1 \quad$ Antenna bipectinate (male) ..............................................................2

- $\quad$ Antenna simple (female) (Note: female of $P$. reducta unknown) ...............12

2 Hindwing black except fringe, scales tiny, hair-like exposing membrane, appearing glassy (label can be read through wing); Caribbean: Hispaniola (Fig. 3).

P. reducta

- Hindwing with white scales, or if without white scales dark scales not greatly reduced, wing opaque ....................................................................... 3

3 Small (FW length $14-15 \mathrm{~mm}$ ); wing pattern blurred or appearing out of focus; uncus obsolete (Fig. 45); aedeagus without sclerotized cornuti, but armed with patch of many soft fleshy-appearing spines (Figs. 1, 45)

P. apanthea

- $\quad$ Larger (FW length $16 \mathrm{~mm}$ or more); wings with lines clear, contrasting; uncus present; aedeagus armed with 1-2 large sclerotized cornuti (Figs. 46-57)......4

4 Terminus of uncus bifurcate (Fig. 48)

P. gigantea

Terminus of uncus not bifurcate; square, rounded or pointed (Figs. 46, 47, 49-57)

Everted vesica long, narrow, 3-5 $\times$ long as wide (Figs. 54-56)

Everted vesica short, bulbous, $1-2 \times$ long as wide (Figs. 46-53) ................8

Vesica with large bent or curved terminal cornutus (Fig. 56); sw USA

Vesica with large straight terminal cornutus (Figs. 54-55); eastern USA and Canada 
Vesica with second smaller cornutus near base of vesica (Figs. 55, 57), southeastern USA (Fig. 71)

P. furcilla australis

Vesica without second cornutus (Fig. 54); eastern USA and Canada (Fig. 71) (Note: specimens from zone where furcilla and australis meet show intermediate characters)

P. furcilla furcilla

Vesica with large curved claw-like basal cornutus and finger-like diverticulum with a small straight terminal cornutus (Fig. 50). P. virginarius Vesica without finger-like diverticulum (Figs. 46-49) (Note: some specimens of virginarius from Wyoming and southern Idaho may have a greatly reduced diverticulum with a very small or obsolete spine) (Fig. 51). Vesica with two large, curved, approximately equal-sized cornuti (Fig. 59) ...

Vesica with two prominent cornuti, one much smaller in size (Figs. 46; $52-$ 53)

Vesica with one short curved cornutus and one long, thin, straight or recurved cornutus; clasper simple, not scoop-shaped or forked (Figs. 52-53) 11 Vesica with large basal and small terminal cornutus; large scoop-shaped clasper (Fig. 46)

P. judyae Wings with prominent white areas (Figs. 36-38); eastern and boreal North America (Fig. 71). .P. acronyctoides acronyctoides Wings without prominent white areas, or if white area present, confined to small areas of outer edge of FW postmedian line and anal angle of HW (Figs. 40-43); Rocky Mountains and foothills (Fig. 71)

P. acronyctoides nigra Sterigma vestigial or obsolete (Fig. 58); sw USA P. apanthea Sterigma well developed (Figs. 59-68)..... Corpus bursae with thick-walled opaque upper and thin-walled translucent lower sections (Figs. 65-68) 14 Corpus bursae single, an oval or oblong, thin-walled translucent sac (Figs. 59-64)

Ductus bursae narrow, finely folded or "corrugated," expanding abruptly to corpus bursae (Figs. 65-67); eastern USA and Canada Ductus bursae wider, with large folds, widening gradually and with folds extending onto upper section of corpus bursae (Fig. 68); sw USA (Fig. 71)......

Ductus bursae strap-like, few twists and folds (Fig. 67); east and se USA (Fig. 71) P. furcilla australis Ductus bursae not strap-like, with many finer "corrugated" folds (Fig. 65); northeastern USA and Canada (Fig. 71) (Note: specimens of ssp. australis and furcilla show intermediate characters where the ranges meet)...... 
17 Ductus bursae heavily sclerotized to or almost to corpus bursae (Fig. 61)...... P. guatemala

- $\quad$ Ductus bursae with heavily sclerotized part extending no more than half way to corpus bursae (Figs. 59-60)

18 Ductus bursae between sterigma and corpus bursae narrow; corpus bursae tear-drop or oval shape (Fig. 59); FW length less than $25 \mathrm{~mm}$....... P. judyae

- $\quad$ Ductus bursae below sterigma wide; corpus bursae oblong (Fig. 60); FW length greater than $25 \mathrm{~mm}$.

P. gigantea

19 Ductus bursae slightly curved, smooth, with expanded rim at ostium (Figs. 63-64) 20

- $\quad$ Ductus bursae straight, wrinkled, without expanded rim at ostium (Fig. 62)

20 Wings with prominent white areas (Figs. 36-38); eastern and boreal North America (Fig. 72) P. acronyctoides acronyctoides

- Wings without prominent white areas (Figs. 40-43); Rocky Mountains and foothills (Fig. 69) (Note: specimens of acronyctoides show intermediate characters in central Alberta) P. acronyctoides nigra

\section{Panthea apanthea species-group}

The Panthea apanthea species-group contains only P. apanthea.

Panthea apanthea Anweiler, sp. n. urn:lsid:zoobank.org:act:A120BA18-CACF-4F2C-A9D5-E7CB60A1E2D4 Figs. 1-2, 45, 58, 69

Type material. Holotype male - "[United States] White Mts. AZ [Arizona] / El. 7200-12500 ft./ 10-30 Aug 1925./ O. C. Poling coll”; "Barnes collection"; "HOLOTYPE / Panthea apanthea / Anweiler" [red label]; "Photographed by J.D. Gill (CNC)/ 260" [orange label]; deposited in USNM.. Paratypes (8 $\mathrm{O}^{\lambda}, 2$ q): Arizona: Coconino Co., Oak Creek Canyon, 5000', 6.viii.1986, R.H. Leuschner, coll. (1 đ̊); same locality and collector, 7.viii.1986 (2 đ); Coconino Co., 7 miles west Williams, 8-15.viii.1956,

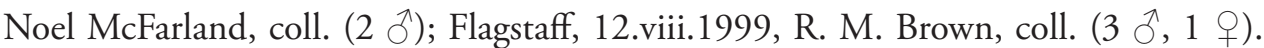
Colorado: El Paso Co., 20 miles east Colorado Springs, 18.viii.1965, Sam Johnson (1 đ); Starr Ranch nr. Colorado Springs, 16.viii.1965, 6600', Sam Johnson, coll. (1 + [CNC; RHL; RMB].

Etymology. The name is Latin and means "not Panthea," and refers to the unusual structure of the genitalia, which differ so much in appearance from other American Panthea.

Diagnosis. The typical Panthea pattern will identify P. apanthea to genus, and the very small size will separate it from all other western Panthea, with the possible excep- 
tion of very small males of $P$. judyae. The lack of any sharply contrasting black lines on the forewings will separate it from all other Panthea. Internally the lack of sclerotized spines on the vesica and the lack of a heavily sclerotized sterigma are unique to $P$. apanthea, and unusual for Panthea.

Description. Male and female moderately dimorphic, female larger and with darker hindwing than male; forewing length: 4-15 mm (male), $18 \mathrm{~mm}$ (female). Head - male antenna bipectinate, pectinations approximately $1.5 \times$ as long as width of antennal shaft, female antenna simple; palps greatly reduced, clothed in dark brownish-gray hair-like scales. Thorax - collar, thorax and tegulae a mix of dark black-brown and white hair-like scales; tegulae with two poorly defined oblique bands; femur and tibia clothed in a mixture of black and white hair; tarsus banded black and white. Dorsal forewing - with an even mixture of brownish-black and white scales, appearing gray. Lines black but not strongly contrasting with ground and difficult to trace. Basal line indicated by a small patch of black scales, antemedial line black, complete, more prominent than other lines, straight to anal vein, bending distad before continuing to lower margin; medial line faint, slightly erratic, less prominent than basal line and difficult to trace in some specimens, merging or nearly so with black scales at end of cell; postmedial line slightly more prominent and more erratic, bending distad at fold and wandering outward toward costa; subterminal line erratic, bordered on distal side mainly on upper half by a few white scales; terminal line black, broken at veins; fringe black, lightly checkered with white at veins. Normal spots obsolete, except reniform spot indicated by a small, dark, poorly defined crescent or bar at end of cell; veins lightly lined with dark scales. Dorsal hindwing (male) - white with four very faint diffuse bands formed by tiny hair-like scattered gray scales, with long pale-gray hairs along inner margin and a dark gray-black terminal line; fringe dark gray black, lightly checkered at veins. Dorsal hindwing (female) - as in male, but with a heavier dusting of small dark scales forming wider bands, appearing light gray overall. Abdomen - covered with short stiff brownishblack and white hair-like scales. Male genitalia - (Fig. 45) valve relatively short, sacculus large, extending two-thirds distance across valve, with rows of small sawlike teeth along inner ridge; cucullus extending only a short distance beyond clasper, ending in a small wing-like flap folding in toward clasper; clasper large with almost half length extending past upper margin of valve, straight, tapering to a wide base; tegumen with ear-like subuncal lobes; uncus nearly obsolete, reduced to a pair of widely spaced flat rounded lobes, reminiscent of arachnid palps; aedeagus $2 \times$ as long ventrally as dorsally; inflated vesica a short oblong sac, about $2 \times$ as long as wide, exiting aedeagus at 90 degrees dorsad, with a large teardrop-shaped field of densely packed fleshy-appearing spines on right side near terminus; ductus exiting from terminus of vesica, oriented anteriorly. Female genitalia - (Fig. 58) papillae anales large, soft, oblong, with sparse fine long setae; posterior and anterior apophyses approximately equal in size and of average length; sterigma poorly developed, lightly sclerotized, with two large shallow indentations above ostium; ductus bursae short, wide, expanding into a thicker walled wrinkled section with a series of parallel 
wrinkled and sclerotized "gullies" along dorsal wall, widening gradually into an oblong, thin-walled translucent corpus bursae, without signa; ductus seminalis exiting dorsad on upper right.

Distribution and biology. Panthea apanthea is known from only 10 specimens and from only three areas in the southwestern United States; Coconino County and Apache County (White Mountains) in Arizona, and El Paso County in east-central Colorado (Fig. 69). It has been collected at moderate elevations (1500-2150 m) during the first three weeks of August. Nothing else is known of its biology.

Remarks. The essentially obsolete uncus, poorly developed sterigma, and the replacement of the one to three large cornuti found on the aedeagus in all other species of New World Panthea by a dense patch of fleshy spines (Fig. 45), are all unique among the New World Panthea. However, similar fields of small spines are present in other genera of Pantheinae e.g., Lichnoptera decora (Morrison) (Fig. 44), Colocasia coryli (L.), as well as in Panthea ronnyi Thony, recently described from North Vietnam (Thony 1996). This suggests that the large sclerotized cornuti present in all other New World taxa is a derived character, and that $P$. apanthea is the most basal of the New World Panthea. Panthea apanthea has such divergent genitalia that an argument could be made for placing it in a genus of its own; however, in all other characters (form of the bipectinate antenna in male; reduced, apparently non-functional mouthparts and palps; overall color and pattern) it is placed in Panthea to maintain a more inclusive concept of the genus. DNA 'barcode' fragment data of $\operatorname{cox} 1 \mathrm{mtDNA}$ (Ratnasingham and Hebert 2007) also places apanthea with Panthea.

\section{Panthea reducta species-group}

The Panthea reducta species-group includes only P. reducta.

\section{Panthea reducta Anweiler, sp. n.} urn:Isid:zoobank.org:act:B84ACB81-796A-43FD-89C9-BEFB55E0FFC4 Figs. 3, 47, 70

Type material. Holotype male - "Republica Dominicana: / Pedemales; P.N. Sierra de Bahoruco / Caseta 2; 18¹2.24' N 71³1.11' W / 12 v 2004 el. 1790 m A Luz Murcurio / coll. D. Lawrie and C. Nuñez"; HOLOTYPE / Panthea reducta / Anweiler" [red label]; deposited in CNC [for eventual return to Dominican Republic]. Paratypes - (4 §): Dominican Republic, same data as holotype, except 1 §, 11.vi.2004 [CNC - for eventual return to Dominican Republic].

Etymology. The name refers to the greatly reduced size and density of scales on the hindwing.

Diagnosis. P. reducta can be recognized as a Panthea by the typical Panthea forewing pattern, and by structural characters including the reduced and apparently non- 
functional mouthparts and characteristic modified Panthea uncus. The glassy translucent hindwing is unique in Panthea. It is also the only Panthea known from the Caribbean. Females are unknown.

Description. Head - male antenna bipectinate, pectinations about $2 \times$ as long as width of antennal shaft; head and collar clothed in long dense white, lightgray, and brown-black hair-like scales. Thorax - with long dense white and black hair-like scales, tegulae crossed midway and along edge by poorly defined dark bands. Dorsal forewing - length $16-18 \mathrm{~mm},(\mathrm{n}=4)$, ground a mixture of white, gray-brown and black scales; basal line indicated by a small patches of black scales; antemedial line black, erratic, angled distad at anal vein; medial line broad, incomplete and poorly defined, most prominent as patches of black scales below cubital vein and at and below costa; postmedial line black, slightly erratic, angled outward below vein $\mathrm{Cu} 2$, defined by white scales bordering distal side; subterminal line parallel to postmedial line, starting at anal angle, almost obsolete and defined by white scales outlining distal border; fringe gray with bright white outer edge, checkered with white at veins. Dorsal hindwing - translucent, clothed in tiny hair-like black scales, some finely forked at the tip under magnification, mixed with sparse long dark hair, densest along inner margin; white scales confined to small area along upper and lower margin; fringe black, with white tips in some specimens, checkered at veins with white; wing membrane exposed by reduced scales, glassy, translucent, allowing the lettering on label below to be clearly discerned through wing. Abdomen - clothed in short stiff lead-gray and white hair-like scales. Male genitalia (Fig. 47) valve simple, short and broad, approximately $2 \times$ as long as wide; cucullus bluntly rounded; clasper well-developed, slightly flattened, rod-like with a blunt tip, about $1 / 2$ as long as width of valve at midpoint; tegumen with pair of small subuncal lobes; uncus approximately $2 \times$ as wide as high, resembling a duck's beak; tapering gradually to a broad, blunt terminus; aedeagus short, thick, about $3 \times$ as long as wide; inflated vesica bulbous, short, wide, shaped like a hammer head, armed with a single large sharp curved cornutus on dorsal side near base, oriented anteriorly; ductus seminalis exits near base of vesica on dorsal side.

Distribution and biology. $P$. reducta has been collected at $1800 \mathrm{~m}$ elevation in a Hispaniolan pine (Pinus occidentalis Swartz) forest in Sierra de Bahoruco National Park in the Dominican Republic (Fig. 70). Hispaniolan pine is the presumed larval host.

\section{Panthea judyae species-group}

The Panthea judyae species-group is comprised of three species that occur in pine forests of western North America south to Guatemala in Central America: P. judyae, $P$. gigantea, and P. guatemala. The group is characterized by a large bifurcate scoop-shaped clasper, bulbous vesica with two large curved cornuti and anterior oriented ductus in the male, and a large, massively sclerotized sterigma in the female. 


\section{Panthea judyae Anweiler, sp. n.}

urn:lsid:zoobank.org:act:77024DF7-A3FD-4FB4-850F-E2B6E54E11F9

Figs. 4-5, 46, 59, 69

Type material. Holotype male: "USA [United States of America]: NEW MEXICO: / Socorro Co. [County]. Cibola N. F. [National Forest]. / pine forest, elev. 7620' / $33^{\circ}$ 55.1' N 107 36.9' W / 28 July 1991 / Eric H. Metzler"; "HOLOTYPE / Panthea judyae / G.G. Anweiler" [red label]; "Moths of AB \& BC / Barcode Voucher / G.G. Anweiler" [pink label]; "UASM 99688"; deposited in CNC. Paratypes: 8 ô, 2 ․ United States. New Mexico: same data as holotype, 1 ; Grant Co., Gila National Forest. at Emory Pass, Eric Metzler (2 §); Grant County., Big Burro Mountains, Gila National Forest, Tyrone Rd. 3 mi. west of Hwy. 90 (13 mi. SSW Silver City), 32³7.10'N, $108^{\circ}$ 24.34' W, 6300', 12.viii.2001, at MV light in Ponerosa Pine forest, D. Lawrie (2 ठ); Pinos Altos (above Silver City), 1981 m. el., 14.viii.1987, Ron Leuschner, coll. (1 ठ̂); Arizona: Cochise Co., Huachuca Mountains, Copper Canyon, 1829 m, 30.vii.2000, B. Walsh, coll. (1 $⿱$, 1 o $)$. (CNC; USNM; LACM; UASM).

Additional material examined. $4 \hat{O}, 1$ f from northern Mexico that are slightly larger and darker than the type material and have been excluded from the type series. Two additional male specimens from Arizona missing abdomens are also excluded: Mexico: Chihuahua, Sierra de la Catarina, 18 road miles southwest Buenaventura, 2408 m. el., 21.viii.1976, J.P. \& K.E. Donahue, coll. (1 ठ̋); Sierra de Choreachic Microwave Station on Hwy. 16, 14 road miles west Cuauhtemoc, 2316m, 22.viii.1976, J.P. and K.E. Donahue, coll. (1 đ̊); Creel, 13.vii.1968, T. McCabe, coll. (1 + ); same

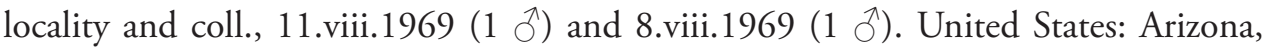
Cochise Co., Huachuca Mountains, Sunnyside, 9.vii.1958, Lloyd Martin, coll. (2 ð).

Etymology. I take pleasure in naming this moth after my wife, Judy Weisgarber, in appreciation for her patience and support in her role as "moth widow."

Diagnosis. The combination of small size (male FW length 16-19.5 mm; female $22 \mathrm{~mm}$ ) and white hindwing will separate $P$. judyae from all other Panthea except $P$. apanthea. The more complete and strongly contrasting black lines on the forewing and the massive sterigma and prominent uncus will separate $P$. judyae from $P$. apanthea.

Description. Sexually dimorphic, female significantly larger and with darker hindwing than male; forewing length of male $17-19 \mathrm{~mm}$, female $21-22 \mathrm{~mm}$; male with bipectinate antenna, female with simple antenna. Head - male antenna with pectinations $1.5 \mathrm{x}$ as long as width of antennal shaft; palps reduced, clothed in dark gray and black scales, frons light gray with scattered black hair-like scales. Thorax - collar and thorax a mixture of light-gray, dark-gray and black hair-like scales; tegulae with two oblique black stripes; legs densely covered with long brownish-black and gray hairs; tarsus banded light gray and black. Dorsal forewing - grizzled or powdery gray, produced by an even mixture of very pale-gray and dark brownish-black narrow scales; basal line indicated by a few black scales; antemedial line prominent, black, straight; medial line similar to antemedial line but angled slightly toward base between veins $\mathrm{CuA} 2$ and $1 \mathrm{~A}+2 \mathrm{~A}$; postmedial line more oblique, angled toward base below vein $\mathrm{M} 3$, approaching 
or meeting medial line between veins $\mathrm{CuA} 2$ and $1 \mathrm{~A}+2 \mathrm{~A}$ before angling slightly distally before reaching lower margin; subterminal line erratic and mostly obsolete, marked with black from costa to near vein M1, then traceable by lighter scales bordering distal side; veins on outer third of wing lightly lined with dark scales; fringe dark brownish black with scattered white scales; reniform spot faintly indicated at end of cell by an oval or crescent of darker scales. Female forewing proportionally broader than male; color and markings as in male but slightly darker gray. Dorsal hindwing - male white with long gray hair along the inner margin and small patches of light-gray scales along leading edge, at cell, and forming an indistinct postmedial band ending in a gray patch where it meets margin at anal angle; veins lined with gray brown scales; terminal line narrow, brownish black; fringe white with scattered dark scales. Female hindwing darker than that of male, crossed by three broad, poorly defined gray bands with areas between bands mixed with scattered gray scales creating an overall gray tone hardly contrasting with forewing; fringe an even mix of dark and light scales, with white scales marking veins. Abdomen - with short, stiff brownish-gray scales, paler at joints and appearing slightly banded. Male genitalia - (Fig. 46) valves simple in form, heavily sclerotized, cucullus rounded to a rough ragged terminus; clasper scoop-shaped with double bladelike arms, upper arm extending across valve to or just beyond upper margin, lower arm much shorter and buttressing upper arm; tegumen with two ear-like subuncal lobes; uncus with a wide base and raised crown ridge, tapering to a narrow, rounded terminus; aedeagus short, curving down and flaring into a plate-like extension on lower side, which appears to support inflated bulbous vesica that exits aedeagus ventrad at almost 90 degrees; vesica armed with a large slightly curved cornutus on right side near base and a similar but much smaller cornutus at apex; vesica tapering abruptly into a long narrow dorsally oriented ductus seminalis. Female genitalia - (Fig. 59) papillae anales a pair of soft, curved bands clothed with sparse long hair; sterigma massive, heavily sclerotized, fused above ostium; ductus bursae short and very broad, thickly sclerotized for about $1 / 2$ its length, slightly farther on right side, narrowing abruptly to neck of nonsclerotized thin-walled teardrop-shaped corpus bursae; bursa covered in rows of minute spicules visible under higher magnification; without signa.

Distribution and biology. Panthea judyae has been collected in the Mogollon and Big Burro Mountains of southwestern New Mexico, the Huachuca Mountains of southeastern Arizona, and the Sierra Madre Occidental of northern Mexico, at elevations of 1800-2400 m (Fig. 69). Collection dates range from July 9-August 28. Two of the Arizona specimens were collected in Ponderosa pine forest.

\section{Panthea gigantea (French)}

Figs. 6-9, 48, 60, 70

Platycerura gigantea French 1890: 134.

Panthea gigantea (French); Smith 1891: 34; Franclemont and Todd 1963: 134.

Diphthera gigantea (French); Draudt in Seitz 1924: 18. 
Type material. Platycerura gigantea was described by French from a single male received from David Bruce from Colorado, where he is known to have traveled and collected widely (Brown 1966). A search for the type, which was retained by French (Smith 1893), has been unsuccessful and it is apparently lost, possibly in the fire that destroyed much of his collection in 1892 (Southern Illinois University Carbondale 2009). As it appears the present concept of $P$. gigantea may encompass more than a single taxon, the following neotype is designated to establish stability of the name: Neotype male - "CO [Colorado] / Larimer Co.[County]"; "Estes Park [40 22.315" N $105^{\circ} 31.645^{\prime}$ W] / 15 July 1993 / R. A. Belmont / UV BL"; "NEOTYPE / Platycerura / gigantea French / Anweiler 2009" [red label]; deposited in CNC. The neotype is a male missing the left antennae and showing minor greasing, but is otherwise in good condition.

Diagnosis. Panthea gigantea is on average the largest New World species of Panthea with some females having a wingspan in excess of $6 \mathrm{~cm}$. Only P. guatemala from southern Mexico and Guatemala and some populations of $P$. virginarius from the western USA overlap $P$. gigantea in size. The male of $P$. gigantea can be recognized by the combination of large size (FW length $22-27.5 \mathrm{~mm}$ ), dark gray-black, or graybrown (Mexico only) forewing and contrasting white hindwing, and can be separated from all other New World Panthea by the unique bifurcate uncus. The female of $P$. gigantea can be separated from that of $P$. guatemala by range (Fig. 70 ) and by the much less extensively sclerotized ductus bursae of $P$. gigantea (Fig. 60) and from the female of $P$. virginarius (Fig. 61) by the much larger and more heavily sclerotized sterigma of $P$. gigantea.

Distribution and biology. Panthea gigantea is found throughout much of the warmer and drier regions of western North America from south-central British Columbia, Canada south to the state of Durango, Mexico and from the Black Hills of South Dakota, western Nebraska and the Texas Panhandle west to Washington, Oregon and the coast of California (Fig. 70). Panthea gigantea is replaced in the cooler and more humid Pacific Northwest and northern Rocky Mountain regions by P. virginarius. Panthea gigantea is associated with Ponderosa pine forest (Pinus ponderosa Dougl. [ex Laws.]), and Ponderosa pine is the only known larval host. (Duncan 2006; Anweiler unpub.). The larva of $P$. gigantea was illustrated in color by Duncan (2006).

Remarks. Compared to material from farther north and west, specimens of $P$. gigantea from Arizona and New Mexico show differences in the genitalia of both sexes, including in the proportions and shape of the valve in the male and the width and length of the ductus bursae in the female. DNA 'barcode' fragment data of cox $1 \mathrm{mtD}$ NA for 6 specimens from Arizona and New Mexico show a mean difference of about $1.7 \%$ from two specimens from Idaho and British Columbia, and sequence from a single specimen from west central California is about $1.8 \%$ divergent from the IdahoBritish Columbia samples and about $0.8 \%$ divergent from the Arizona-New Mexico samples (Anweiler unpublished data). The forewings of the four Mexican specimens examined are gray brown instead of gray black with a less "powdery" appearance, so the antemedial, medial and postmedial lines contrast much more prominently than on 
non-Mexican material (Figs. 8, 9). Additional and more recent material is needed in order to evaluate the taxonomic status of these different $P$. gigantea populations.

\section{Panthea guatemala Anweiler, sp. n.} urn:lsid:zoobank.org:act:B73B5B00-C011-41B9-B7A2-0F285C41234E Figs. 10-11, 49, 61, 70

Type material. Holotype male - "GUATEMALA / San Lorenzo 1700 m [15 $7.002^{\prime}$ N 89³7.998' W] / 6-10.vi.1986 / P.T. Dang"; "HOLOTYPE / Panthea / guatemala / G.G. Anweiler" [red label]; deposited in CNC. Paratypes (17 §, 2 †): same data as holotype (10 §); MEXICO. Chiapas: Lagos de Colores, Route 17, 13.vi.1969, A. Mutura, coll. (1 §); San Cristobal, 21 miles southeast, Rt.190, 1850 m, 30.vi.1989, Wolfe, Valverde and Mullins, coll.(1 §); Tapilula, 21.vi.1969, A. Mutuura (2 ठ). Oaxaca: Tierra Azul, 3 mi. n. Tlaxiaco, 7.viii.1992, 7500', H. Romack., coll. (1 ð); 7 mi. s. Miahuatlan, 19.viii.1992, 7000', H. Romack, coll. (1 $\delta^{\top}, 1$ o ); 3 mi. e. La Trinidad, 2.viii.1992, 8500', H. Romack, coll. (1 đ̊); Sierra Juarez, Gulf slope, 4500', 8.iv.1992, J. Kemner, coll., (1 ㅇ); Sierra Madre del Sur, ca. 32 km N. San Gabriel Mixlepec, 1590 m., 10.vii.1991, J. Kemner and H. Romack, coll. (1 Ô). [LACM; CNC; NYSM].

Etymology. The name refers to the country Guatemala, where the holotype and much of the type series originated.

Diagnosis. Panthea guatemala is externally very similar to $P$. gigantea from northern Mexico. Their large size will separate them from all other Mexican Panthea except $P$. gigantea. Both sexes of $P$. guatemala can be separated from $P$. gigantea by range (Fig. 70) and by genitalic characters, the male by the narrow fused uncus (Fig. 49), which is bifurcate in $P$. gigantea, and the female by the laterally compressed and heavily sclerotized ductus bursae of $P$. guatemala (Fig. 61). Both sexes of $P$. guatemala have a faint but consistent white streak on the lower forewing from just basad of the antemedial line to just beyond the postmedial line; this streak is absent or much fainter in P. gigantea.

Description. Sexually dimorphic; female larger and with broader forewing and darker hindwing than male; forewing length of male $22-25 \mathrm{~mm}$, female $27-28 \mathrm{~mm}$. Head - male antenna bipectinate with pectinations about $1.5 \times$ as long as width of antennal shaft; female antenna simple; palps and frons a mix of dark brownish-gray and white hair-like scales. Thorax - collar and thorax a mix of dark brownish-gray and white hair-like scales; tegulae crossed by two diffuse oblique brownish-black bands; legs densely covered with long wooly gray-black and white hairs; tarsi banded white and gray. Dorsal forewing (male) - a mix of white and brownish-gray scales producing a smooth pale brownish-gray ground; basal line poorly marked; antemedial, medial and postmedial lines prominent, black; basal and antemedial lines straight or nearly so, medial line sinuous, bending outward at cubital vein then continuing almost straight to lower margin; postmedial line straight to vein M2, then bending inward and connecting with medial line in fold, diverging outward just before reaching lower margin; 
subterminal line nearly obsolete, very erratic, curving inward between veins $\mathrm{M} 1$ and M3, M3 and CuA1, CuA1 and $1 A+2 A$, and defined by abrupt shift from gray to white scales, shading back to gray prior to reaching margin. A short, thin poorly defined black bar marks end of cell, and a faint diffuse white dash runs parallel to and below cubital vein between antemedial and postmedial lines. Fringe gray brown lightly checkered with white scales at veins. Dorsal forewing (female) - as in male but broader, more rounded and with fewer white scales and therefore darker overall. Dorsal hindwing (male) - white with long gray-brown hair, darkest in basal area and along inner margin; leading edge light gray; poorly defined faint light-gray medial and postmedial bands, latter terminating in a patch of gray at anal angle; narrow dark-gray terminal line; veins narrowly lined with dark gray; fringe white with a few dark scales between veins. Dorsal hindwing (female) - suffused with gray, medial band narrow, postmedial band much wider leaving only a narrow band of lighter scales along margin; terminal line wider than in male; fringe dark gray with a few white scales, checkered with white at veins. Abdomen - clothed with stiff brownish-gray hair. Male genitalia - (Fig. 49) valves simple, heavily sclerotized, cucullus rounded to a blunt ragged point; clasper large, scoop-shaped with double blade-like arms, inner branch longer, extending beyond upper margin of valve; tegumen with two large squared subuncal lobes; uncus flattened laterally with high rounded crown curving down, ending in narrow terminus bluntly to sharply truncated; aedeagus about $4 \times$ as long as wide, somewhat flattened, flaring at terminus; vesica bulbous, tapering gradually into long ductus seminalis angled dorsad at about 45 degrees, oriented anteriorly; armed with two large cornuti, one on right near base, other larger and near crown. Female genitalia - (Fig. 61) papillae anales large, soft, thinly covered with stiff hairs, fused at base on dorsal side; sterigma massive, rounded, relatively smooth; ductus bursae wide, twisted to right, compressed laterally, thickly sclerotized for half its length or more before gradually flaring into corpus bursae; corpus bursae an oblong thin-walled sac, without signa.

Distribution and biology. Panthea guatemala has been collected in the mountains of Guatemala and the states of Oaxaca and Chiapas in adjacent southern Mexico at elevations of 1580-1850 m (Fig. 70). Collection dates range from late May to late July (Mexico) and early November (Guatemala). The Guatemala specimens were collected in pine-oak forest at $1700 \mathrm{~m}$.

\section{Panthea furcilla species-group}

The $P$. furcilla species-group is closely related to the $P$. acronytoides group. It includes two species, $P$. furcilla (Packard) and $P$. greyi sp. n. Panthea furcilla is further segregated into two subspecies, with $P$. furcilla australis ssp. n. described as new. The group is characterized by the long, narrow vesica, 3-5 x as long as wide when everted and inflated, armed with a large terminal cornutus (Figs. 54-56), and by the elongated corpus bursae, partially constricted mesially forming a thick-walled outer section and a translucent thin-walled inner section (Figs 65-68). 
Panthea furcilla furcilla (Packard)

Figs. 12-18, 54, 65, 71

Platycerura furcilla Packard, 1864: 3: 331.

Panthea furcilla (Packard); Smith 1891: 31; Smith and Dyar 1898:15; Dyar 1902: 98;

Smith 1903: 98; Barnes and McDunnough 1917: 83; McDunnough 1938: 54;

Franclemont and Todd 1983: 134.

Diphthera furcilla (Packard); Draudt. In: Seitz 1924: 18.

Panthea furcilla pallescens McDunnough, 1937: 153; McDunnough 1938: 54. New synonymy.

Panthea pallescens McDunnough, 1942; Forbes 1954: 291; Franclemont and Todd 1963: 134.

Panthea pallescens centralis McDunnough, 1942: 94; Franclemont and Todd 1983: 134. New synonymy.

Panthea pallescens var. atrescens McDunnough, 1942; Franclemont and Todd 1983: 134. unavailable infrasubspecific name. New synonomy.

Type material. Platycerura furcilla Packard, 1864. (2 syntypes, one apparently lost). The extant syntype is a dissected male in MCZ, Cambridge MA bearing the following labels: "Furcilla Type"/ "M.C.Z. Type 26319"/Platycerura furcilla Pack. Type"/ "745"/\#245" and is accompanied by a slide preparation of the valves, aedeagus with everted vesica, and abdominal pelt, with two labels reading "MCZ 1139"/ and "\#MZ -1 Platycerura furcilla Pack. Type J.G. Franclemont." This specimen is hereby designated as lectotype and a label printed on red card reading "Lectotype/ Platycerura furcilla Pack./ G.G. Anweiler 2009" will be placed with the specimen. Dorsal and ventral images of the specimen, the slide and all labels except the lectotype label are available online at http://insects.oeb.harvard.edu/MCZ/FMPro.

Type Locality: Massachusetts, USA.

Panthea furcilla pallescens McDunnough, 1937. Holotype male, CNC, examined. Type locality: White Point Beach, Queens Co., Nova Scotia, Canada.

Panthea pallescens centralis McDunnough, 1942. Holotype male, CNC, examined. Type Locality: Norway Bay, Québec, Canada.

Panthea pallescens var. atrescens McDunnough, 1942. Holotype male, CNC, examined. Type Locality: Norway Bay, Québec, Canada. Unavailable infra-subspecific name.

Diagnosis. The genitalic characters defining the $P$. furcilla species-group (inflated vesica elongate with a single terminal cornutus in the male; corpus bursae partially constricted creating two sections in the female) will separate $P$. furcilla from all other Panthea except $P$. greyi. The male of $P$. furcilla can be separated from that of $P$. greyi by range ( $P$. greyi west of the Great Plains from Colorado south, $P$. furcilla in Canada and eastern United States east of the Great Plains), and by the much smaller, straighter, terminal cornutus on the vesica. The female of $P$. greyi has a wide ductus bursae that gradually expands into the corpus bursae; $P$. furcilla has a narrow ductus that expands 
abruptly into bursa. Nominate $P$. furcilla can be separated from ssp. australis by the second, smaller cornutus near the base of the vesica in australis.

Distribution and biology. Panthea furcilla occurs widely in coniferous woodlands, in particular pine forests, throughout eastern USA and eastern Canada, from eastern Texas east to Florida, north to the northern edge of the boreal forest in Canada, west to northeastern British Columbia (Fig. 71). Adults fly almost year round at the southern edge of the range in Texas and Louisiana (V. Brou pers. comm.), with the flight period shortening to June and July in boreal Canada.

Remarks. For the past 50 years, since McDunnough (1942) treated pallescens as a species apart from $P$. furcilla, the name pallescens has generally been applied at the species level to the smaller, lighter gray populations of Panthea occurring widely across the northeastern United States and boreal Canada; they are characterized as having a single cornutus on the vesica. The name furcilla has generally been used for the larger, darker Panthea in southeastern United States that has a second smaller "rose-thorn" cornutus on the vesica near the base. McDunnough sent specimens from eastern Canada and from New Jersey to a Dr. Banks to compare with the type of furcilla in MCZ, and based on the response he received, concluded that the male genitalia of furcilla had a short, thick pointed cornutus in the vesica and an apical spine of the so called rosethorn type. The primaries were of a rather even purplish gray with all cross-lines very heavy and black with scarcely any white edging except on the outside of the subterminal line (McDunnough 1942). Based on this information, McDunnough elevated the pale northern population that he had initially described as ssp. pallescens to species status (McDunnough 1942). However, examination of images of the male type of furcilla and in particular the genitalic slide, shows clearly that the type of furcilla is a specimen of the smaller, paler northern Panthea lacking the second "rose-thorn" cornutus, and that the name pallescens is a junior synonym of furcilla.

The relationship of these two forms, one smaller and paler with a single cornutus and one larger and darker with a second cornutus (and corresponding differences in the female genitalia) is problematic. There is no clear-cut boundary between the two populations, and no place where the two occur together. Although differing significantly from each other in size, color and genitalic structures over most of their range, specimens gradually shift in all characters from one type to the other across a band from Kentucky north and east through southern Pennsylvania, Maryland and New Jersey (Figs. 19-20, $56 \mathrm{a}-\mathrm{d}, 66$ ). This appears to be another example of a species separated during the last glacial maximum into populations northwest and southeast of the Appalachians that have since re-established contact, as has been proposed for Grammia virgo by Schmidt (in press). Arguments can be made for recognizing these two taxa as either species or as subspecies; however based on the fact that they show a progressive gradation from one form to the other in color, pattern and genitalic structures, as well as the fact that the two forms do not occur together anywhere, I treat these populations as a single species. The southern form is described as a new subspecies.

True melanic specimens of $P$. furcilla (Fig. 18) are common in some populations of nominate form in eastern United States (Klots 1964, Klots 1966, Klots 1968; Ginevan 
1971). Melanic specimens are overall sooty brown with the black lines standing out. Form atrescens (Fig. 16) from Ontario and Quebec is a black and white form, very different in appearance from true melanic specimens.

\section{Panthea furcilla australis Anweiler, ssp. $\mathbf{n}$.}

urn:lsid:zoobank.org:act:F22C8E8D-9DAE-4C15-A215-6BD0ED85D641

Figs. 21-24, 55, 67, 71

Panthea furcilla of authors, not Packard, 1864.

Type material. Holotype male - United States. "GEORGIA: Whitfield Co.[County] / Rocky Face Area / 16.x.1992, at light / J. K. Adams"; "HOLOTYPE / Panthea furcilla / ssp. australis / Anweiler" [red label]; "UASM\# 57801"; [34 48.311 N $85^{\circ} 1.655$ W]. deposited in CNC. Paratypes (12 $\partial^{2}, 7$ O ): UNITED STATES: Georgia: Whitfield County, Rocky Face area, 3.viii.1992 (1 đ̂); 14.x.1992 (1 ठ̂); 27.iv.1993 (1 đ̂);

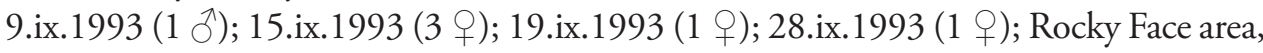
junction Hwys. 41/201, 27.iv.1992 (2 ठ̂); Dalton area, 19.iv.1991 (1 q); 25.v. 1991(1

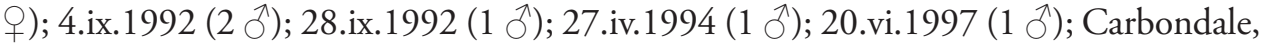
exit 326 off I-75, 23.iii.2002 ( 1 §ै); all J.K. Adams, coll. [CNC; UASM; USNM; JKA]

Etymology. Australis is Latin for southern and refers to the fact that australis occupies the southern part of the range of $P$. furcilla.

Diagnosis. Panthea furcilla australis can be separated from all Panthea species other than those of the $P$. furcilla species-group by the characters given above in the $P$. furcilla species-group diagnosis. The larger size, darker gray color and in particular the presence of a second cornutus on the vesica of the male, will separate males of australis from those of both $P$. greyi and nominate $P$. furcilla. Females of ssp. australis can be recognized by the larger size and darker color, and by the narrow sclerotized strap-like ductus bursae with few folds compared to the narrow and finely corrugated ductus of nominate $P$. furcilla and wide, deeply wrinkled ductus of $P$. greyi. Intermediate specimens from the zone of contact along the northwestern side of the Appalachian Mountains, from Kentucky north and east to southern Pennsylvania and New Jersey, can be recognized by the gradual loss of the australis characters, and in particular in the gradual reduction in the size of the smaller cornutus in the vesica of the male. These three taxa are also separated by range, with australis in southeastern United States, nominate furcilla in the northeastern United States and Canada, and P. greyi in the southwestern United States (Fig. 71).

Description. Sexes dimorphic, with female larger and darker than male; male forewing length $18-22 \mathrm{~mm}$; female forewing 24-25 mm. Head - male antenna bipectinate, female antenna simple; Palps reduced, clothed in dark red-brown and black scales. Thorax - and tegulae a mixture of dark red-brown and pale gray or white hairlike scales, appearing gray; tegulae with an oblique black medial band and black edging. Dorsal forewing - ground a mixture of black and white scales, appearing light 
gray powdered with black, crossed by five prominent black lines; Basal line indicated by small patches of black scales, antemedial line complete, straight or nearly so, medial line complete, angled distad slightly in most specimens to meet postmedial line in fold before separating and slanting basad to lower margin; postmedial line similar in form to medial line to about vein M1, bending basad to meet medial line in fold before angling distad to lower margin; subterminal line broad, erratic, usually incomplete, jutting outward between veins R4 and R5, at veins M1 and M2, and at lower margin of wing; area distad to lower postmedial line and in particular distad to subterminal line suffused with white scales; fringe dark gray or black, checkered with white at veins; faint pale gray longitudinal streak on basal half of wing above and below cubital vein. Dorsal hindwing - dull gray, slightly darker in basal half, with faint dark medial band, diffuse postmedial band; terminal band white, incomplete, often reduced to a narrow marginal patch of white scales, especially in female; fringe white between veins with gray on veins. Abdomen - clothed in short, stiff light and dark-gray hair-like scales. Male genitalia - (Fig. 55) valve simple, cucullus tapering to a blunt terminus; clasper simple, flat, blade-like s-shaped, arising from lower margin at distal end of sacculus, approximately as long as valve is wide at that point; tegumen with large triangular subuncal lobes; uncus laterally compressed with a high crown, tapering to a rounded terminus with a flattened tip; aedeagus $4-5 \times$ as long as wide, slightly bent ventrad, expanding at apex, terminating in a semi-detached or detached plate on left side bearing a prominent, sharp cornutus; inflated vesica long and narrow, approximately $4 \times$ as long as wide, bending ventrad near base and expanding into a slight pouch before gradually tapering to terminus; armed with a large, sharp terminal cornutus; ductus seminalis exiting at right-angle dorsad near base of vesica. Female genitalia - (Fig. 67) papillae anales short, wide, soft, curved, with sparse setae; sterigma well-developed and sclerotized, but not massive; ductus bursae heavily sclerotized, strap-like, 3-4 $\times$ as long as wide, bent and twisted near middle with several longitudinal folds or corrugations in posterior half, expanding abruptly into a large oblong corpus bursae, partially constricted midway, forming approximately equal-sized upper and lower sections; upper section with partially sclerotized, thickened walls; lower section thin-walled, translucent; without signa.

Distribution and biology. $P$. furcilla australis occurs in pine woods throughout the southeastern United States from eastern Texas and Florida north approximately to Virginia (Fig. 71). A single specimen has also been seen from Oregon County in southeastern Missouri. Panthea furcilla australis intergrades with nominate $P$. furcilla in a band along the northwest side of the Appalachian Mountains; specimens from Kentucky, Maryland, southern Pennsylvania and New Jersey are variably intermediate.

A series of specimens in MSU labeled as collected in Starr County, Texas is assumed to be mislabeled, as there is no coniferous habitat in Starr Co. (C. Bordelon pers. comm.).

Specimens of australis from northern Georgia were seen from every month from March through October. In Louisiana it has been collected year-round, with peaks at approximately 30-day intervals except in May and June (V. Brou pers. comm.). 


\section{Panthea greyi Anweiler, sp. n.}

urn:lsid:zoobank.org:act:0225DA43-EDA5-458B-AE4D-64188BAB8944

Figs. 25-27, 57, 68, 71

Type material. Holotype male - UNITED STATES "AZ [Arizona] Cochise Co.[County] $7700 \mathrm{ft} /$ Chiricahua Mtns [Mountains], Onion / Saddle MV lights / 4 Aug 2000 J.B. Walsh leg."; "HOLOTYPE / Panthea greyi / Anweiler" [red label]; [31

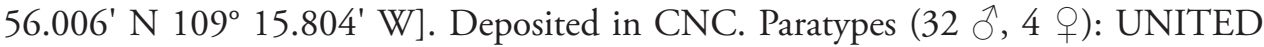

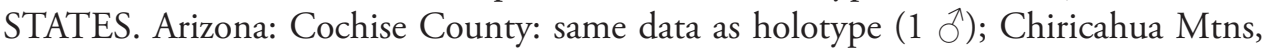
Pinery Canyon, Upper Camp, 5.vii.1956, 1 ภ, 1 ㅇ); same locality and coll., 6.vii.1956 $(1$ đ); same locality, 7.vii.1956, Lloyd Martin, John A. Comstock and Will. A. Rees, coll. (2 đ)); Chiricahua Mtns, Pinery Canyon, 6800', 26.vii.1965, RH Leuschner, coll. $\left(2{ }^{\top}\right)$; same locality and coll., 26.vi.1992 (1 §); Pinery Canyon cmpgd, $31.93^{\circ}$ N 109.27 W, 6500' 5.viii.08 C. Schmidt and B. Walsh (3 3). Apache Co., White Mountains, Greer, 8300', 1-3.vii.1993, R. Leuschner, coll. (2 §); same locality and coll., 24-25.vii.1965 (2 ठ̊); same locality and coll., 8200', 6.vi.1990 (1 ठ̂); Greer, 28-30.vii.2005, James Adams and Doug Yanega, coll. ( 1 đ); Junction Hwy. 260-373, 2.vii.1986, Pat Savage, coll. (1 §). Graham Co.: Pinaleno Mtns, Mt. Graham, Pine Crest, 7300', 28.vi.1955, Lloyd Martin, John A. Comstock and Will. A. Rees, coll. (1 ð). Coconino Co.: Oak Creek Canyon, 5000', 6.viii.1986, RH. Leuschner, coll. (1 §̂); same locality and coll., 7.viii.1986 (1 đ)); same locality and coll., 5500', 23.vii.1989 $(1$ đ̊). Gila Co.: Mogollon Rim, Tonto Creek State Fish Hatchery, 6400', 21.vi.957, Lloyd M. Martin, Robert J. Ford and William A. Rees, coll. (1 1 ). New Mexico: Colfax Co.: Sangre de Cristo Mts., Cimarron Canyon, 7900', 7.vii.1962, E. and I. Munroe,

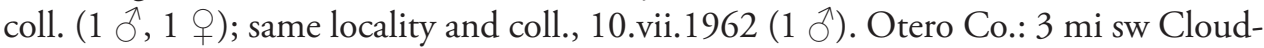
croft, 8830', 23.v.2006, Greg Forbes, coll. (1 +); Sacramento Mtns, Dry Canyon Rd., 2.1 mi. n. Rte 82, 6 mi. east Rt. 244 at Cloudcroft., G. Forbes, coll. ( 1 ô). Lincoln Co.: Ruidosa, Cedar Creek campground, 7000', 28.vii.1962, E. and I. Munroe, coll. (1 +). Grant Co.: Gila National Forest at Emory Pass, 3252.5'N 107²45.0'W, 7160', 5.viii.1991, E. Metzler, coll. (1 §̋). Colorado: Larimer Co.: Big Thompson Canyon, 6500', 9.vii.1955, R.H. Leuschner, coll. (1 đ̋). Archuleta Co.: Pagosa Springs, 7000', 7.vii.1988, R.H. Leuschner, coll. (1 §). Teller Co.: Florrisant, Big Springs Ranch, 14.viii.1960, TC. Emmel, coll. (1 đ)); same locality and coll., 12.viii.1960 (1 đ). Boulder Co.: Left Hand Canyon, 6000', 22.vii.958, RH. Leuschner, coll. (2 ठ).

Etymology. I take pleasure in naming this species in honor of the late L. Paul Grey, who encouraged my budding interest in noctuid moths and who sent me the first specimen of this new Panthea.

Diagnosis. Panthea greyi belongs to the $P$. furcilla species-group, and can be separated from all Panthea with the exception of $P$. furcilla by the characters listed in the diagnosis for the group, namely the elongate vesica with one terminal spine in the male and the two-chambered corpus bursae in the female. It can be separated from $P$. furcilla by range, with $P$. greyi occurring in southwestern United States west of the Great Plains and $P$. furcilla east of the Great Plains in eastern United States and north of the Great 
Plains in Canada. Externally, P. greyi is most similar to Panthea virginarius and Panthea acronytoides nigra. $P$. virginarius occurs west and north of the range of $P$. greyi. Panthea acronyctoides nigra may occur with $P$. greyi in northern Colorado where $P$. greyi can be recognized by the light, banded hindwing and $P$. acronyctoides by the dark hindwing, as well as by the genitalic characters. Panthea gigantea is a larger species with two cornuti in the male vesica and a single chambered, thin-walled corpus bursae in the female.

Description. Sexes similar and overlapping in size, female only slightly darker than male; male forewing length 19-22.5 mm, female 21-25 mm. Head - Male antenna bipectinate, with pectinations about $2 \times$ as long as width of antennal shaft; female antenna simple; palps reduced, both palps and lower part of frons clothed in dark redbrown or black hairs; remainder of head a mixture of light-gray, dark-brown and black hair-like scales. Thorax - collar, thorax and tegulae a mixture of light gray, dark brown and black hair-like scales; tegulae crossed by two oblique dark bands midway and along outer edge; legs clothed in dense long light gray and dark gray hair, tarsus banded black and white. Dorsal forewing - ground a mix of white or very light gray and dark brownish-black scales, appearing powdery gray; crossed by five black lines; basal line marked by one or two small patches of black scales; antemedial line straight or nearly so, bending distad in fold before continuing to wing margin; medial line most prominent, straight except for bending distad slightly in fold before reaching lower margin; postmedial line narrower, erratic, bent distad at each vein and angling basad below vein CUA1, contacting or closely approaching medial line below veins $\mathrm{CuA} 2$ before bending distad to lower margin of wing; subterminal line incomplete, often reduced to a few dark patches of scales near upper margin, erratic, defined by white scales along distal side; fringe dark gray black, checkered with a few white scales at veins; small black bar or crescent marking the end of the cell. Abdomen - clothed in short, stiff dark gray-brown hair, paler at joints. Dorsal hindwing - white with long gray hair-like scales along inner margin, crossed by poorly defined light gray antemedial, medial and postmedial bands and with a narrow dark gray terminal line; fringe checkered with dark gray and white; veins narrowly lined with dark scales. Male genitalia - (Fig. 57) valve simple, elongate, cucullus rounded, clasper a simple prominent blade near apex, about as long as width of valve; tegumen with large triangular earlike subuncal lobes; uncus laterally compressed with crown approximately as high as wide; ending in a rounded terminus resembling a duck's beak viewed from above; inflated and everted vesica long, narrow, about 3-4 x as long as wide, angled to left midway and armed with a single massive slightly bent or curved terminal cornutus, oriented toward head; ductus seminalis exiting midway at right angle to right. Female genitalia - (Fig. 68) papillae anales a pair of soft curved bands with sparse hairs; posterior and anterior apophyses about equal in size and of average length; sterigma well-developed, average in size and amount of sclerotization; ductus bursae wide, about $2 \times$ as long as wide, mostly heavily sclerotized with deep creases and folds, expanding gradually into posterior section of corpus bursae; corpus bursae slightly constricted midway, forming a thick-walled and partially sclerotized posterior section united with lower half of ductus, and a thin-walled, translucent globular anterior section. 
Distribution and biology. Panthea greyi has been collected in the mountains of Arizona, New Mexico, Colorado and southern Utah, at elevations of 1524-2545 m (Fig. 71). Collection dates range from June 6 through September 23. It has been collected in Arizona in oak-pine woodland.

\section{Panthea acronyctoides species-group}

The $P$. acronyctoides species-group contains a single species pair, $P$. acronyctoides and $P$. virginarius, with $P$. acronyctoides populations arranged into two subspecies. The male is characterized by the bulbous vesica armed with a pair of unequal-sized cornuti, the female by the globular or oval single chambered corpus bursae and a short wide ductus, about $2 \times$ as long as wide. Both species have populations with a strongly contrasting black and white pattern, very similar in external appearance to each other and to the Palaearctic species $P$. coenobita (Esper), but not found in any other North American species. The $P$. acronytoides group appears to be most closely related to the $P$. furcilla group. DNA cox-1barcode sequence data shows little differentiation within or between the two groups (Anweiler unpubl. data).

\section{Panthea acronyctoides acronyctoides (Walker)}

Figs. 36-38, 53, 64, 72

Audela acronyctoides Walker, 1861: 37.

Panthea leucomelana Morrison, 1876: 428.

Diphthera acronyctoides (Walker); Draudt 1924 In: Seitz 1924: 18

Panthea acronyctoides (Walker); McDunnough 1937: 153; Franclemont and Todd 1983: 134.

Panthea acronyctoides albosuffusa McDunnough, 1937: 153; Franclemont and Todd 1983: 134. New synonomy.

Type material. Audela acronyctoides: Holotype male, Montcalm Co., Quebec, Canada, in CNC. The holotype male is in poor condition (photograph examined).

Panthea leucomelana: described by Morrison from 2 specimens, from Maine and New Hampshire. According to Smith (1893), Morrison's type is in the Tepper collection, which resides in MSU. There is a single specimen, from "Maine" in the Tepper collection at MSU, presumed to be one of the two Morrison types; the other specimen is apparently lost (Wilterding 1997). The Maine specimen bears a Lectotype label placed there by J. H. Wilterding; however this action was never published (Wilterding pers. comm.). I hereby designate this specimen as Lectotype of P. leucomelana Morrison. A label printed on red cardstock reading "LECTOTYPE"/ Panthea / leucomelana Morrison / G.G. Anweiler" will be affixed to this specimen. 
Panthea acronyctoides var. albosuffusa. Holotype male, White Point Beach, Queen's Co., Nova Scotia, Canada (in CNC, type \#4223). The holotype and $3 \stackrel{\delta}{3}+$ paratypes from Nova Scotia, Canada in CNC (examined).

Diagnosis. Throughout most of its range, nominate Panthea acronyctoides can be recognized by smaller size and black and white or gray and white pattern. The only other Panthea species occurring with nominate $P$. acronyctoides is $P$. furcilla, a larger and darker gray and black species. In western North America, ssp. nigra, occurs with both P. greyi and $P$. virginarius. Both subspecies of $P$. acronyctoides can be separated from all other Panthea by the combination of a small spine and a second long thin spine on the male vesica, and smooth-walled ductus bursae with an expanded rim in the female.

Remarks. Although described as a subspecies by McDunnough, albosuffusa is clearly a form as pointed by Forbes (1954), who refers to a brood reared from eggs produced by a female albosuffusa that produced about $1 / 4$ albosuffusa, $1 / 4$ typical and $1 / 2$ melanic specimens (Forbes 1954). Specimens of small dark dwarfed populations of $P$. acronyctoides have been seen from bogs in the southern four tiers of counties in Michigan. These are much smaller and darker than $P$. acronyctoides found elsewhere, and are possibly environmentally induced by the cool wet habitat they occupy. The genitalia of these specimens do not differ from those of typical $P$. acronyctodes except in size.

Distribution and biology. Nominate $P$. acronyctoides is found throughout much of the wooded parts of eastern and northern North America, from northern Georgia north to Newfoundland and Nunavut, west across the northeastern tier of states and southern and central Canada to Alberta. It intergrades with ssp. nigra in central Alberta (Fig. 72). Nominate $P$. acronyctoides occupies a range of coniferous habitats, including spruce, larch, fir and mixed forest.

The larva of $P$. acronyctoides is described and illustrated by Brown and McGuffin (1942).

\section{Panthea acronyctoides nigra Anweiler, ssp. $\mathbf{n}$.}

urn:lsid:zoobank.org:act:D0C7898C-597C-4D4D-918B-18C07D689FC9

Figs. 40-43, 52, 63, 72

Panthea angelica of authors, not Dyar, 1921.

Panthea virginarius of authors, not Grote, 1880.

Type material. Holotype male - "USA [United States of America], CO [Colorado]. Gilpin Co. [County] / Rooseveldt N. F. Cpg [National Forest Campground] / 3 km S Nederland, 2600 m / 12.vii.1993, MVL / leg. B. Landry"; "HOLOTYPE / Panthea acronyctoides / ssp. nigra / Anweiler" [red label]; [39 $55.103 \mathrm{~N} 105^{\circ} 30.46$ W], deposited in CNC. Paratypes: 21 ô, 1 q) UNITED STATES: Colorado: Gilpin Co.: Lump Gulch, 9.vii.1955, Hugo Rodeck, coll. (1 §̂); Allenspark, 1415.vii.1982, W.D. Winter, coll. (1 ð). Grand Co.: Harbison Picnic Area, RMNP [Rocky Mountain National Park], 8450', 7.vii.1995, P.A. Opler, coll. (1 Ô, 1 ○); 
same locality, 13.viii.1995, P. A. Opler and E. Buckner, coll. (1 ठ̊); St. Louis Creek, vic. of Fraser, 8.vii.1988, Jack Oder, coll. (1 ß̋). Teller Co.: Florissant, 4.ii.1993, M.R. Belmont, coll. (1 đ̂). RMNP, Sprague's, 22.vii.1933, Grace H. and John L. Sperry, coll. (1 đ). Wyoming: Albany Co.: 0.4 mi. sw Fox Park, T13N R78W S21, 9040', 26.vii.1999, J. Nordin, coll. (3 đ); same date and collector, Fox Park at Fox Creek, T13N R78W S21, 9040' (3 đ̋); Hidden Valley Picnic Ground, T14N R72W S35, 8540', 6.vii .1999, J.S. Nordin, coll. (2 ○); Upper Blair PG [Picnic Ground] n. of Rd. 705, T14N R71W S7, 8200', 8.vi.2000, J.S. Nordin, coll.(1 §̋); Telephone Creek, s. of Hwy. 130, T16N R79W S14, 13.vii.1999, 10170', J. S. Nordin, coll., (1 ठ); T15N R72W S35, 8550', 12-13.vi.2000, C.D. Ferris, coll. (1 ð); T13N R78W S21, 9060',vic. FR 530, 26-27.vii.1999 (1 ठ̋); T14N R71W S7 SE4, 8200', 22-23. vi.1999, C.D. Ferris, coll. (1 §), T15N R71W S18S, 8200', 19-20.vi.1999, C.D. Ferris, coll. $(1$ ふ).

Etymology. The name nigra means black and refers to the overall dark color of the adults of both sexes.

Diagnosis. Panthea acronyctoides nigra can be separated from nominate $P$. acronyctoides by the overall dark coloration and by distribution, nigra in the foothills and mountains of western Alberta and British Columbia south to Colorado, nominate acronyctoides from central and eastern Alberta eastward (Fig. 72). Specimens in central Alberta are intermediate. Subspecies nigra occurs with both P. greyi (Colorado) and $P$. virginarius (north of Colorado). The three species can be very similar in external appearance, but are easily separated by genitalic characters. The male of ssp. nigra (Fig. 52) has two spines on a bulbous vesica, one of which is long and thin, whereas P. greyi (Fig. 56) has a single massive spine on an elongate vesica. The male of nigra can be separated from those of $P$. virginarius by the lack of the massive, curved spine near the base of the vesica present in $P$. virginarius (Figs. 50, 51) The female of nigra can be separated from those of both $P$. greyi and $P$. virginarius by the smooth-walled ductus bursae with an expanded rim (Fig. 63); the ductus bursae in P. virginarius (Fig. 62) and P. greyi (Fig. 68) is wrinkled or folded and without an inflated rim.

Description. Sexes similar, except female on average slightly larger and darker than male; Forewing length $18-21 \mathrm{~mm}$. Head - male antenna bipectinate, female simple; male antennal pectinations about $1.25-1.5 \times$ as long as width of antennal shaft; palps reduced, covered in gray-brown hairs; head and collar gray. Thorax gray; tegulae gray with two oblique black stripes; legs clothed in long gray hair; tarsus banded blackish brown and light gray. Dorsal forewing - ground color a mixture of brownish-black and white scales producing a powdery dark gray appearance, crossed by five black lines that can be difficult to trace against the dark background in many specimens; basal line indicated by a small patch of black scales; antemedial line slightly erratic, angled basad below veins $\mathrm{R}$ and $\mathrm{M}$ and angled distad below vein $1 \mathrm{~A}+2 \mathrm{~A}$; medial line wider and more prominent than other lines, shallowly zigzagged, bending distad below vein $1 \mathrm{~A}+2 \mathrm{~A}$; postmedial line narrow, dragged outward at each vein, bending basad below vein M3 and approaching me- 
dial line, fusing with medial line for a short distance in some specimens before angling distad between veins $\mathrm{CuA} 2$ and $1 \mathrm{~A}+2 \mathrm{~A}$; subterminal line most prominent near costa, angled sharply distad between veins $\mathrm{R} 5$ and M1, becoming diffuse and difficult to trace below, bordered on distal side by lighter gray or white scales; fringe dark gray or black, checkered with small patches of white scales at veins; orbicular spot indicated by a small patch of dark scales in some specimens, and reniform spot by a small crescent or bar at end of cell. Abdomen - clothed in a mixture of short stiff dark-brown and dirty-white hair, appearing faintly banded at joints. Dorsal hindwing - dark brownish gray with faint darker gray medial and postmedial bands, shading to a narrow dark terminal line; veins lightly lined with dark scales; usually with a faint white streak or small patch of white scales near lower margin; fringe white, lightly checkered with gray between veins. Male genitalia - (Fig. 55). valve simple; sacculus with a prominent clasper at distal end, s-shaped, flattened blade-like with a rounded terminus, approximately as long as width of valve at midpoint, supported at base with a small buttress; cucullus bluntly pointed; tegumen with a pair of large rounded or triangular subuncal lobes; uncus modified, laterally compressed with a high crown, about as high as wide, tapering very gradually to a very narrow terminus; aedeagus $3-4 \times$ as long as wide; everted inflated vesica small, rounded, globular, tapering into a long narrow ductus seminalis, oriented distad at a shallow angle, armed with two cornuti, smaller cornutus on right side near apex, second cornutus much longer, thin, straight or slightly recurved, on left side closer to apex. Female genitalia - (Fig. 68) papillae anales squared, soft, clothed with sparse fine setae; sterigma well-developed but not massive, smooth; ductus bursae short and wide, about $2 \times$ as long as wide, with smooth thick walls, expanding into a smooth rim around ostium, resembling mouth of a milk-bottle; corpus bursae a large, thin-walled single-chambered oval or slightly teardrop shaped sac, with rows of minute spicules over much of surface; without signa.

Distribution and biology. Subspecies nigra replaces nominate $P$. acronyctoides in the foothills and mountains of western Alberta westward to central British Columbia and southward in the Rocky Mountains to Colorado; a disjunct population is in the Black Hills of South Dakota (Fig. 72). In Alberta and in the Black Hills of South Dakota, nigra has been collected at elevations of 1220-1370 m, in Wyoming and Colorado to $3050 \mathrm{~m}$. Subspecies nigra occurs in Lodgepole pine (Pinus contorta Dougl. ex Loud.) forests. Five reared specimens from British Columbia in the CNC were obtained from larvae collected on Lodgepole pine. Adult collection dates range from June 8 through August 13.

Remarks. Previous literature reports of $P$. acronyctoides from British Columbia (Smith and Dyar 1898; Forbes 1954; McDunnough 1937) almost certainly refer to black and white specimens of $P$. virginarius, as all museum specimens examined from the Rocky Mountains westward labeled as $P$. acronyctoides were misidentified specimens of $P$. virginarius. Conversely, specimens of $P$. acronyctoides nigra from Colorado were found in institutional collections misidentified as either $P$. angelica (Dyar) or $P$. portandia Grote, new synonyms of P. virginarius. 


\section{Panthea virginarius Grote}

Figs. 29-35, 50-51, 62, 69

Biston virginarius Grote, 1880: 220.

Lycia virginaria (Grote); Dyar 1902: 328.

Panthea virginaria (Grote); Barnes and McDunnough 1917: 83; McDunnough 1938:

54; Franclemont and Todd 1983: 134.

Panthea portlandia Grote, 1896: 14; Dyar 1902: 98; Smith 1903: 98; Barnes and Mc-

Dunnough 1917: 83; McDunnough 1938: 54; Franclemont and Todd 1883: 134.

New synonomy.

Panthea angelica Dyar, 1921: 142; McDunnough 1938: 54; Franclemont and Todd 1883: 134. New synonomy.

Panthea portlandia suffusa McDunnough, 1942: 94; Franclemont and Todd 1883:

134. New Synonomy.

Type material. Biston virginarius: Holotype female, Soda Springs, Shasta Co, California, USA (BMNH). Photograph examined

Panthea angelica: Mt. Lowe, Los Angeles, California, USA. Holotype male (USNM) Photograph examined; genitalia slide apparently lost.

Panthea portlandia: described by Grote from 2 specimens from Portland, Oregon, USA. Types could not be located in either the BMNH or USNM and may be lost.

Panthea virginaria suffusa: described from a holotype male from Dixon Creek, Barriere, British Columbia, Canada. The specimen was reared from a larva collected from Picea englemanni. (Type \#5282 in CNC). Adult and genitalic slide examined.

Diagnosis. Panthea virginarius varies greatly in size and color pattern depending on location and habitat. Both sexes of $P$. virginarius can be very difficult to separate from those of $P$. gigantea where they occur together unless genitalic characters are used. The tip of the uncus can usually be examined without dissection by brushing the scales from the end of the abdomen; the male of $P$. gigantea has a bifurcate tip to the uncus (Fig. 48), P. virginarius does not (Fig. 50). Females can be separated by the structure of the sterigma, which is much larger and more massively sclerotized in $P$. gigantea (Fig. 60) than in $P$. virginarius (Fig. 62). Black and white specimens of $P$. virginarius from southern British Columbia and Idaho (Fig. 35) have been mistaken for nominate $P$. acronyctoides (Fig. 36), but the two taxa are well separated by range (Figs. 69, 72). In the Rocky Mountains from Alberta and British Columbia southward P. virginarius can be confused with $P$. acronyctoides nigra. Panthea virginarius is larger and the male has a paler, banded hindwing than nigra; females can be differentiated by examining the ductus, which is wrinkled in P. virginarius (Fig. 62), smooth with an expanded rim around the ostium in nigra (Fig. 63).

Distribution and biology. Panthea virginarius occurs mainly west and north of the Great Basin, from the coast of southern California northward to the Queen Charlotte Islands of British Columbia and the Alaskan Panhandle, eastward to central California, northern Nevada, Idaho, northwestern Wyoming, western Montana, and southwest- 
ern Alberta; a disjunct population is in the Cypress Hills of Alberta and Saskatchewan (Fig. 69). Large black and white populations (syn. "portlandia") occur along the coast from central California to southern British Columbia. These are replaced by gray and black populations both farther north and farther south along the coast, and at higher elevations inland. Intermediate populations occur at lower elevations eastward as far as western Montana and extreme southwestern Alberta.

Panthea virginarius is found in coniferous forests, in particular but not confined to Douglas-fir forest (Pseudotsuga menziesii (Mirb.) Franco) at elevations ranging from sea-level to near tree-line.

Remarks. Panthea virginarius appears in checklists as both the original spelling virginarius (e.g., Grote 1880; Poole 1989) and virginaria (e.g., Franclemont and Todd 1983 ) with the ending changed from the original spelling for gender congruity. The original spelling is used herein.

The taxonomy of Panthea virginarius has suffered from the same plethora of errors as has occurred elsewhere in the genus, starting with Grote describing virginarius as a geometrid (Biston), and finishing with McDunnough describing suffusa as a form of portlandia because the $P$. virginarius specimens he used for comparison were misidentified specimens of $P$. acronyctoides nigra.

Panthea angelica is a population of $P$. virginarius in southern coastal California (Los Angeles and San Bernardino counties). Internally it is identical to nominate virginarius, and externally differs only by being slightly more suffused with dark scales and thus appearing less powdery. The name angelica has been widely misapplied, both in the literature (e.g., Crumb 1956) and on museum specimens of $P$. greyi and $P$. acronyctoides nigra, lending weight to the apparently mistaken belief that angelica was a good species.

Panthea portlandia is the name that has been applied to the large and striking black and white coastal populations of $P$. virginarius that occur mainly at lower elevations from northern California to southwestern British Columbia. Inland, and at higher elevations, this form intergrades with typical $P$. virginarius, but some of the white shading of the portlandia phenotype is still evident as far east as western Montana and southwestern Alberta. Both white and gray forms occur together at some locations in central Washington. The genitalia are indistinguishable from those of typical $P$. virginarius, so the name portlandia is also placed in synonymy under $P$. virginarius.

Panthea portlandia suffusa was described by McDunnough after comparing it to what he believed were specimens of P. virginarius from Colorado and Alberta, but which were in fact specimens of $P$. acronyctoides nigra. This is evident from his description of the genitalia of $P$. virginarius, which accurately describes $P$. acronyctoides, not portlandia (McDunnough 1942). An examination of his slides in the CNC confirms this. It also explains his puzzling (but accurate) statement that based on the genitalia slides of males from Colorado and Nordegg, Alberta, $P$. virginarius seemed to be merely a large western race of $P$. acronyctoides Walker (McDunnough 1942).

Specimens of $P$. virginarius from northwestern Wyoming tend to be lighter gray, and specimens from Wyoming and adjacent areas of Idaho tend to have the diverticulum of the vesica and its terminal spine greatly reduced in size, and occasionally obsolete. 
The various forms of $P$. virginarius vary greatly in both size and in the proportions of black and white scaling, and thus external appearance varies greatly over a very large geographic area. However, with the exception of specimens in a small area of northwestern Wyoming, little significant variation occurs in the genitalia of either sex, and all are treated as forms rather than subspecies. Further study, particularly in California, may show that one or more populations there should be recognized at the subspecies level, e.g., a silvery-gray population on the Monterey Peninsula that has been reared on Monterey pine (Pinus radiata D. Don) (Frank Sala pers. comm.).

The life history of $P$. virginarius on Vancouver Island, British Columbia. is briefly described by Hardy (1963). The larva and adult female are illustrated in color (as $P$. portlandia) by Miller and Hammond (2003), and the larva is described and illustrated in color by Duncan (2006).

\section{Phylogenetic checklist of New World Panthea}

PANTHEA Hübner, [1820]

ELATINA Duponchel, 1845

AUDELA Walker, 1861

PLATYCERURA Packard, 1864

DIPHTHERA Hampson, 1913, not Hübner, [1809]

apanthea Anweiler, 2009

reducta Anweiler, 2009

judyae Anweiler, 2009

gigantea (French, 1890)

guatemala Anweiler, 2009

furcilla (Packard, 1874)

a. furcilla (Packard, 1874)

pallescens McDunnough, 1937 syn. n.

atrescens McDunnough, 1942, form, unavailable infrasubspecific name centralis McDunnough, 1942 syn. n.

b. australis Anweiler, 2009

greyi Anweiler, 2009

acronyctoides (Walker, 1861)

a. acronyctoides (Walker, 1861)

leucomelana Morrison, 1876

albosuffusa McDunnough., 1937 syn. n., form

b. nigra Anweiler, 2009

virginarius (Grote, 1880)

angelica (Dyar, 1921) syn. n.

portlandia (Grote, 1896) syn. n.

suffusa McDunnough, 1942 syn. n. 


\section{Acknowledgements}

I thank Don Lafontaine, Jim Troubridge, and Chris Schmidt at the CNC for courtesies too numerous to list, in particular for access to the collections in their care and for prodding me to finish this project. Many thanks to Jocelyn Gill (CNC) for photographing specimens and preparing the plates. The following individuals contributed by lending material in their care, or in many cases loans or donations of specimens from their personal collections: Ron Leuschner, Julian Donohue, Paul Opler, Bruce Walsh, Dave Lawrie, Richard M. Brown, James Adams, Mo Nielsen. Martin Honey (BMNH) has, as always, provided information and leads. Felix Sperling and George Ball have provided ongoing encouragement, support, and a base at the Strickland Museum to work in and from. And last but not least my wife Judy, for her ongoing patience and support.

\section{References}

Barnes W, McDunnough J (1917) Check List of the Lepidoptera of Boreal America. Herald Press, Decatur, 392 pp.

Bowman K (1951) An annotated list of the lepidoptera of Alberta. Canadian Journal of Zoology 29: 121-165.

Brown AWA, McGuffin WC (1942) New descriptions of larvae of forest insects. Introduction; 1. Panthea (Lepidoptera, Phalaenidae). Canadian Entomologist 74: 8-12.

Brown FM (1966) David Bruce (1833-1903) and Other Entomological Collectors in Colorado. Journal of the New York Entomological Society 74(3): 126-133.

Crumb SE (1956) The Larvae of the Phalaenidae. U. S. Department of Agriculture Technical Bulletin 1135: 1-356.

Draudt M (1924) Eulenartige Nachtfalter. In Seitz A (1919-1944) Die Gross-Schmetterlinge der Erde. II. Abteilung: Die Gross-Schmetterlinge des Amerikanischen Faunengebietes. Alfred Kernen, Stuttgart, 508 pp.

Duncan RW (2006) Conifer Defoliators of British Columbia. Canadian Forest Service, Natural Resources Canada, 259 pp.

Duponchel PAJ (1844 [1846]) Catalogue Methodique des Lepidoptéres d'Europe. Paris.

Dyar HG (1902) A list of North American Lepidoptera and key to the literature of this order of insects. Bulletin of the United States National Museum 52: 1-723.

Dyar HG (1921) New North American Lepidoptera and records. Insecutor Inscitiae Menstruus 9: 142 .

Forbes WTM (1954) Lepidoptera of New York and neighboring states. Part 3 Noctuidae. Memoirs of the Cornell University Agricultural Experimental Station, Memoirs 329: 1-433.

Franclemont JG, Todd EL (1983) Noctuidae. In: Hodges RW (Ed.) Check List of the Lepidoptera of America North of Mexico. EW Classey Ltd. and the Wedge Entomological Research Foundation London, 120-159.

French GH (1890) Some New Moths. Canadian Entomologist 22: 134-135. 
Ginevan ME (1971) Genetic control of Melanism in Panthea furcilla (Packard) (Lepidoptera: Noctuidae). Journal of the New York Entomological Society 79: 195-200.

Grote AR (1880) New species of North American Moths. Canadian Entomologist 12: 220.

Grote AR (1896) Die Apateliden. Mittheilungen aus dem Roemer-Museum, Hildesheim 3:18 pp. 2 plates.

Hampson G (1913) Catalogue of the Lepidoptera Phalaenidae in the British Museum. Taylor and Francis, London, 609 pp.

Hardy GA (1963) Notes on the life histories of four moths and one butterfly from Vancouver Island. (Lepidoptera Phalaenidae, Lasiocampidae and Lycaenidae). Proceedings of the Entomological Society of British Columbia 60: 35.

Hodges RW et al. (1983) Check List of the Lepidoptera of America North of Mexico. E. W. Classey Ltd. and the Wedge Entomological Research Foundation, London, 284 pp.

Hübner J (1816-1825) Verzeichniss bekannter Schmetterlinge. Augsburg, 431 pp.

Kitching IJ, Rawlins JE (1999) The Noctuiodea. In: Kristensen NP (Ed), Lepidoptera: moths and butterflies. Volume 1: Evolution, systematics and biogeography. Walter deGruyter, Berlin/New York, 355-401.

Klots AB (1964) Notes on melanism in some Connecticut moths. Journal of the New York Entomological Society 72: 142-144.

Klots AB (1966) Melanism in Connecticut Panthea furcilla (Packard) Lepidoptera: Noctuidae). Journal of the New York Entomological Society 74: 95-100.

Klots AB (1968) Further notes on melanism in Connecticut Panthea furcilla (Packard) (Lepidoptera: Noctuidae). Journal of the New York Entomological Society 76: 92-95.

Lafontaine JD (1987) The Moths of North America North of Mexico. Fascicle 27.2. Noctuoidea Noctuidae (Part). The Wedge Entomological Foundation, Washington, 237 pp.

Lafontaine JD (2004) The Moths of North America North of Mexico. Fascicle 27.1. Noctuoidea Noctuidae (Part). The Wedge Entomological Foundation, Washington, 385 pp.

Lafontaine JD, Fibiger M (2006) Revised higher classification of the Noctuidae (Lepidoptera). Canadian Entomologist 138: 610-635.

McDunnough J (1937) Undescribed species and varieties of Lepidoptera. Canadian Entomologist 69: 53.

McDunnough, J (1938) Check list of the Lepidoptera of Canada and the United States of America. Part 1. Macrolepidoptera. Memoirs of the Southern California Academy of Sciences 1: 1-272. McDunnough J (1942) Notes on Pantheinae (Lepidoptera, Phalaenidae). Contribution No. 2138, Division of Entomology, Scientific Service. Department of Agriculture, Ottawa. Canadian Entomologist 74: 93-95.

Miller JC, Hammond PC (2003) Lepidoptera of the Pacific Northwest: Caterpillars and Adults. Forest Health Technology Enterprise Team. U.S.D.A. FHTET-2003-03.

Morrison HK (1876 [1875]) Notes on the Noctuidae with descriptions of certain species. No. 11. Proceedings of the Academy of Natural Sciences and Philosophy 27: 428.

Packard AS (1864) Synopsis of the Bombycidae of the United States. Proceedings of the Entomological Society of Philadelphia 3: 374.

Poole RW (1989) Lepidopterorum Catalogus (New Series). Fascicle 118. Noctuidae, Parts 1-3: E. J. Brill, New York, xii + 1-1314. 
Prentice RM (compiler) (1962) Forest Lepidoptera of Canada. 2. Nycteolidae Noctuidae Notodontidae Liparidae. Canadian Department of Forestry Bulletin 128: 75-281.

Ratnasingham S, Hebert PDN (2007) BOLD: The Barcode of Life Data System. Molecular Ecology Notes 7: 355- 364.

Rosche RC (1989) A partial list of Nebraska moths. mimeographed and distributed by the author.

Schmidt BC (in press) Taxonomic revision of the genus Grammia (Lepidoptera: Noctuidae: Arctiinae). Zoological Journal of the Linnaean Society.

Smith JB (1891) List of Lepidoptera of boreal America. P.C. Stockhausen, Philadelphia, 124 pp.

Smith JB (1893) Catalogue of the lepidopterous superfamily Noctuidea found in boreal America. Bulletin of the United States National Museum 44: 1-424.

Smith JB (1903) Check List of the Lepidoptera of Boreal America. American Entomological Society, Philadelphia, vi + 136 pp.

Smith JB, Dyar HG (1898) Contributions toward a monograph of the Lepidopterous Family Noctuidae of boreal North America. A revision of the species of Acronycta (Ochsenheimer) and of certain allied genera. Proceedings of the United States National Museum 21(1140): 194 pp.

Southern Illinois University Carbondale: George Hazen French (1841-1934). http://www.science.siu.edu/zoology/french/index.html [accessed 25.iii.2009]

Thony H (1996) Zwei neue Arten aus Nord Vietnam, Trisuloides gerri sp. n. und Panthea ronnyi sp. n. (Lepidoptera, Noctuidae, Pantheinae). Facetta 13 (2): 31-36.

Walker F (1861). Audela acronyctoides Walker, M.S.S., n. sp. In: D’Urban WSM. Addenda to the Natural History of the Valley of the River Rouge. Canadian Naturalist and Geologist, 6: $35-41$.

Wilterding JH (1997) Type Specimens of Lepidoptera in the Tepper Collection at Michigan State University. Journal of the New York Entomological Society 105 (1-2): 65-104. 


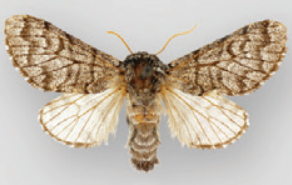

I

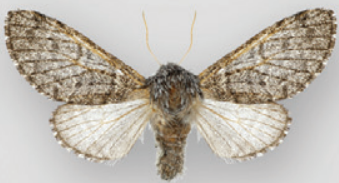

I

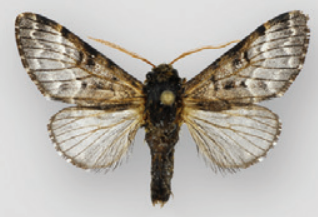

3

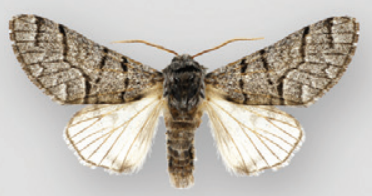

4
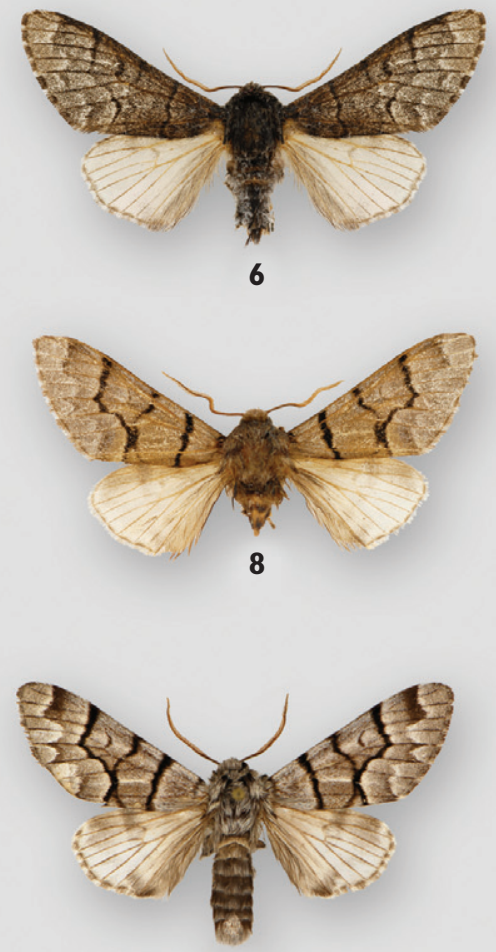

10

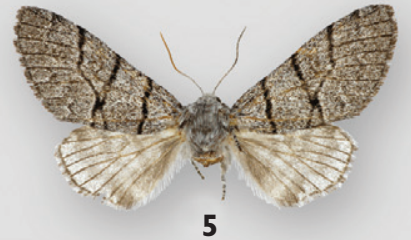

5

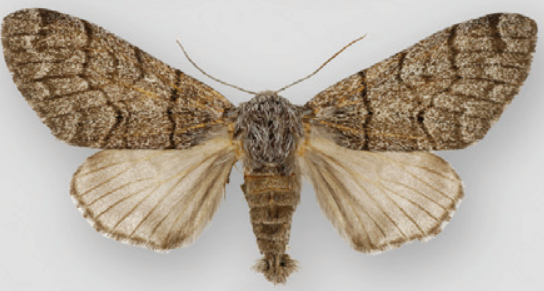

7
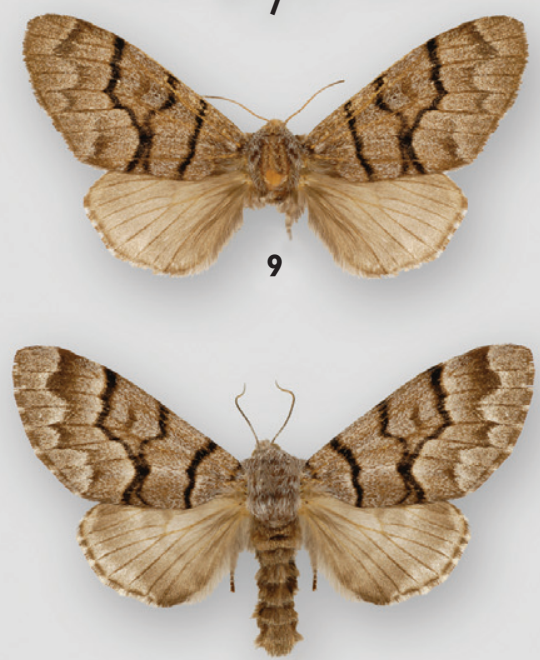

II

\section{Figures I-I I. Panthea adults}

I. $P$. apanthea $\widehat{O}$ holotype, White Mountains, AZ, USA; 2. P. apanthea ${ }_{+}$, Coconino Co., AZ, USA; 3. P. reducta $\widehat{O}$ holotype, Pedemales N.P., DR; 4. $P$. judyae $\widehat{O}$, Grant Co., NM, USA; 5. $P$. judyae $O$, Cochise

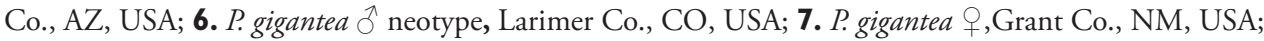

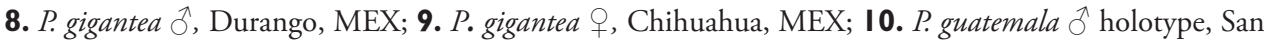
Lorenzo, GUA; I I. P. guatemala $\odot$, Oaxaca, MEX. 


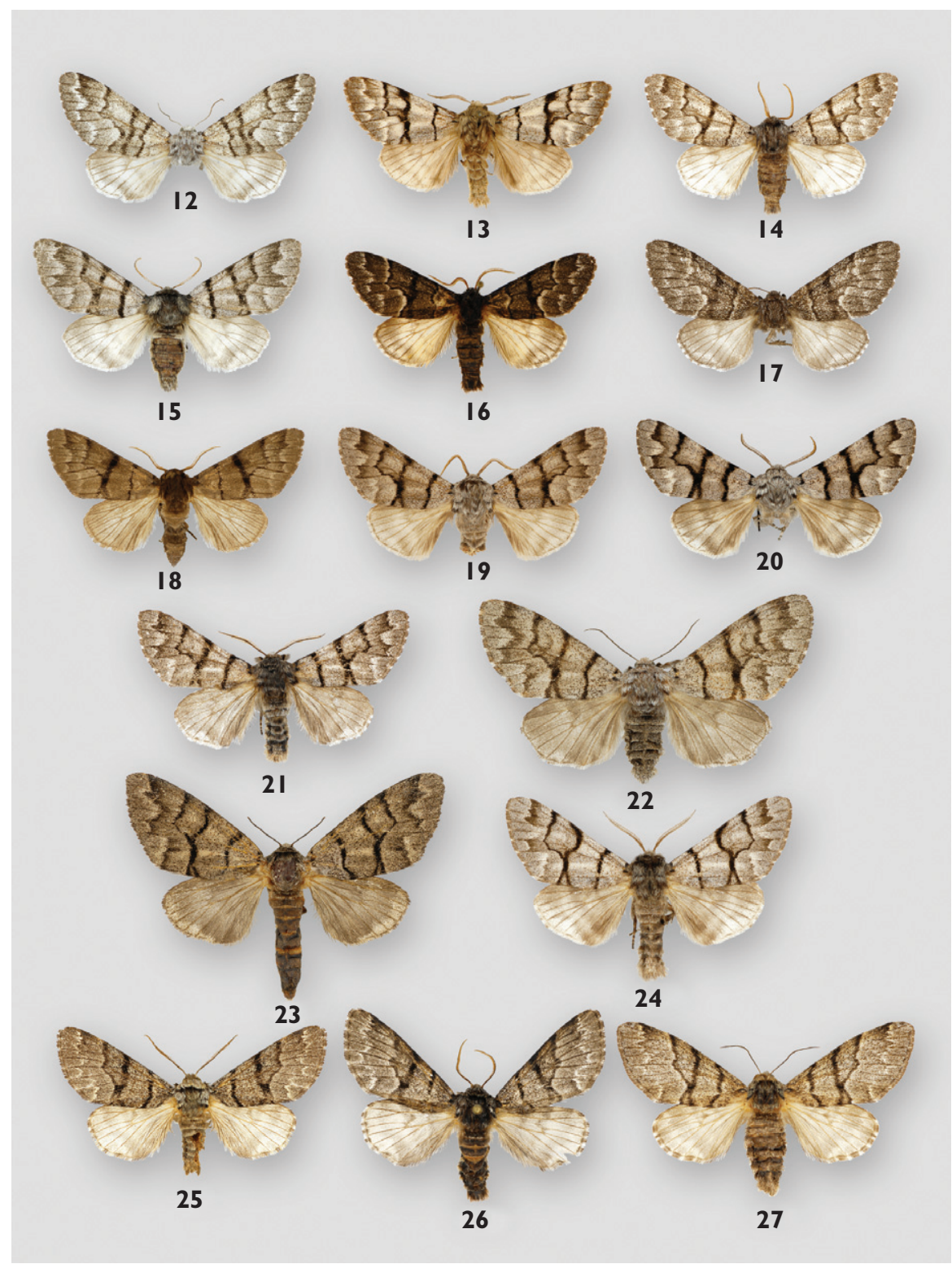

Figures 12-27. Panthea adults

12. P. f. furcilla + , Berkshire Co., MA, USA; 13. P. f. furcilla $\partial$, holotype of pallescens, Queen's Co., NS,

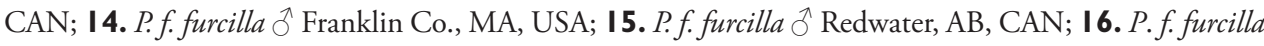

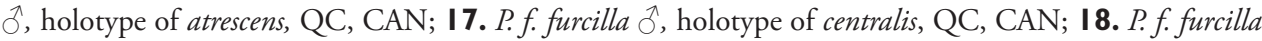
$\widehat{\partial}$ (melanic), Windham Co., CT., USA; 19. P. f. furcilla $-f$. australis intermediate $\partial$, Owsley Co., KY, USA; 20. $P$. $f$. furcilla $-f$. australis intermediate $\hat{O}$, Owsley Co., KY, USA; $\mathbf{2}$ I. $P$. $f$. australis $\hat{\sigma}$ holotype, Whitfield Co, GA, USA; 22. P. f. australis +, Whitfield Co, GA, USA; 23. P. f. australis +, Oregon Co.,

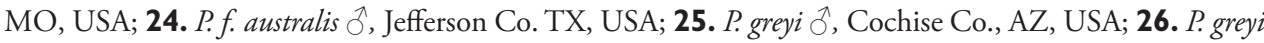
ô holotype, Cochise Co., AZ, USA; 27. P. greyi +, Cochise Co., AZ, USA. 


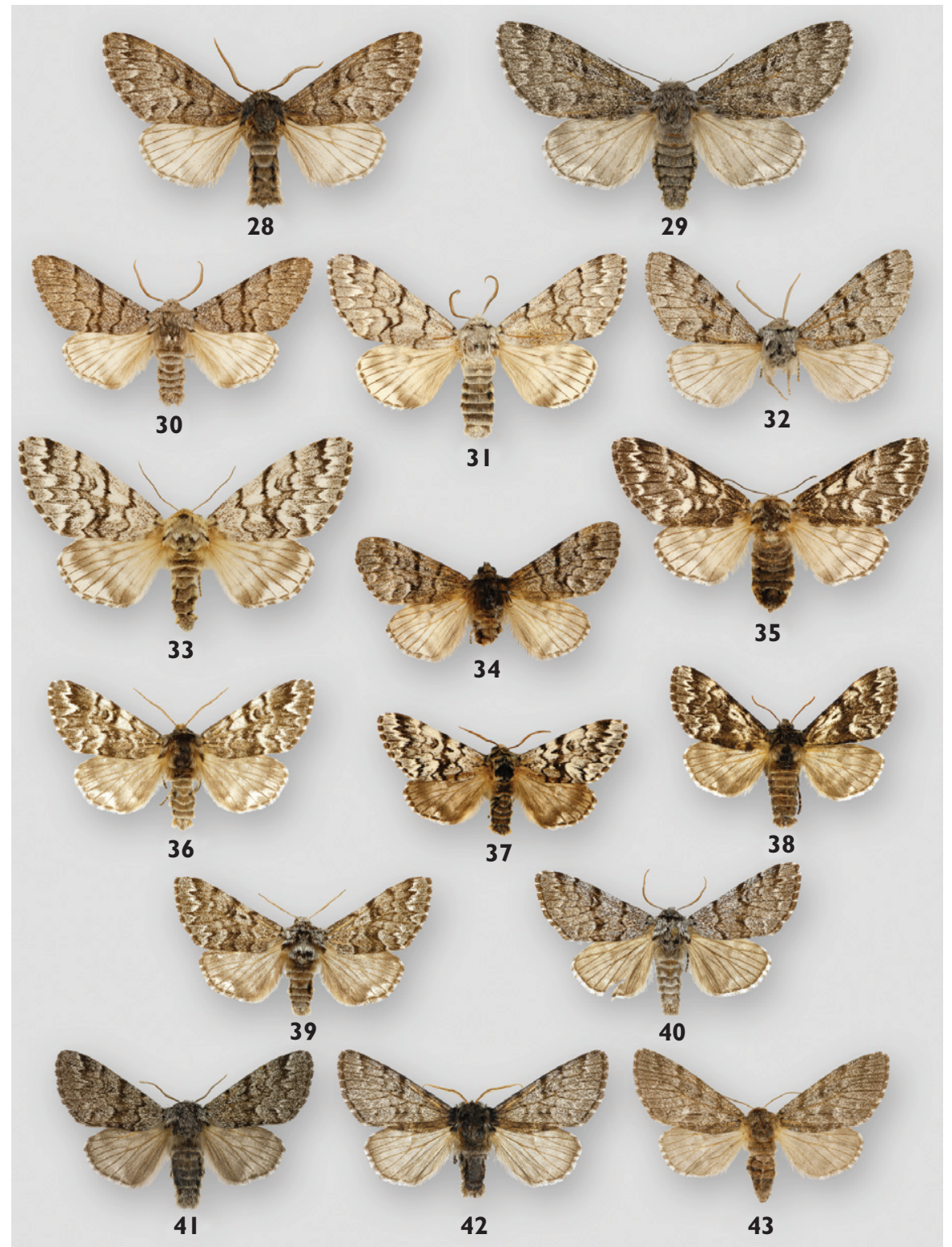

Figures 28-43. Panthea adults

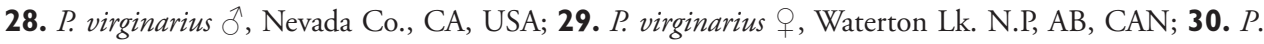
virginarius, $\widehat{O}$, LA Co., CA, USA; 3 I. P. virginarius + , Monterey Co, CA, USA; 32. P. virginarius $\delta$, Lincoln Co., WY, USA; 33. P. virginarius $\odot$, Cowlitz Co., WA, USA; 34. P. virginarius $\widehat{O}$ - holotype of suffusa, Barriere, BC, CAN; 35. P. viginarius, Vavenby, BC, CAN; 36. P. a. acronyctoides $\widehat{\partial}$ Edmonton, $\mathrm{AB}, \mathrm{CAN} ; 37$. $P$. a. acronyctoides, $\widehat{O}$ holotype of albosuffusa, Queen's Co., NS, CAN; 38. $P$. a. acronyctoides Oे, Penobscot, ME, USA; 39. P. a. acronyctoides - a. nigra intermediate, Edmonton, AB, CAN; 40. P. a. nigra $\widehat{\partial}$ holotype, Gilpin Co., CO., USA; 4I. P. a. nigra $\widehat{O}$, Jasper N.P., AB, CAN; 42. P. a. nigra $\widehat{\partial}$, Grand Co., CO, USA; 43. P. a. nigra + , Grand Co. CO, USA. 

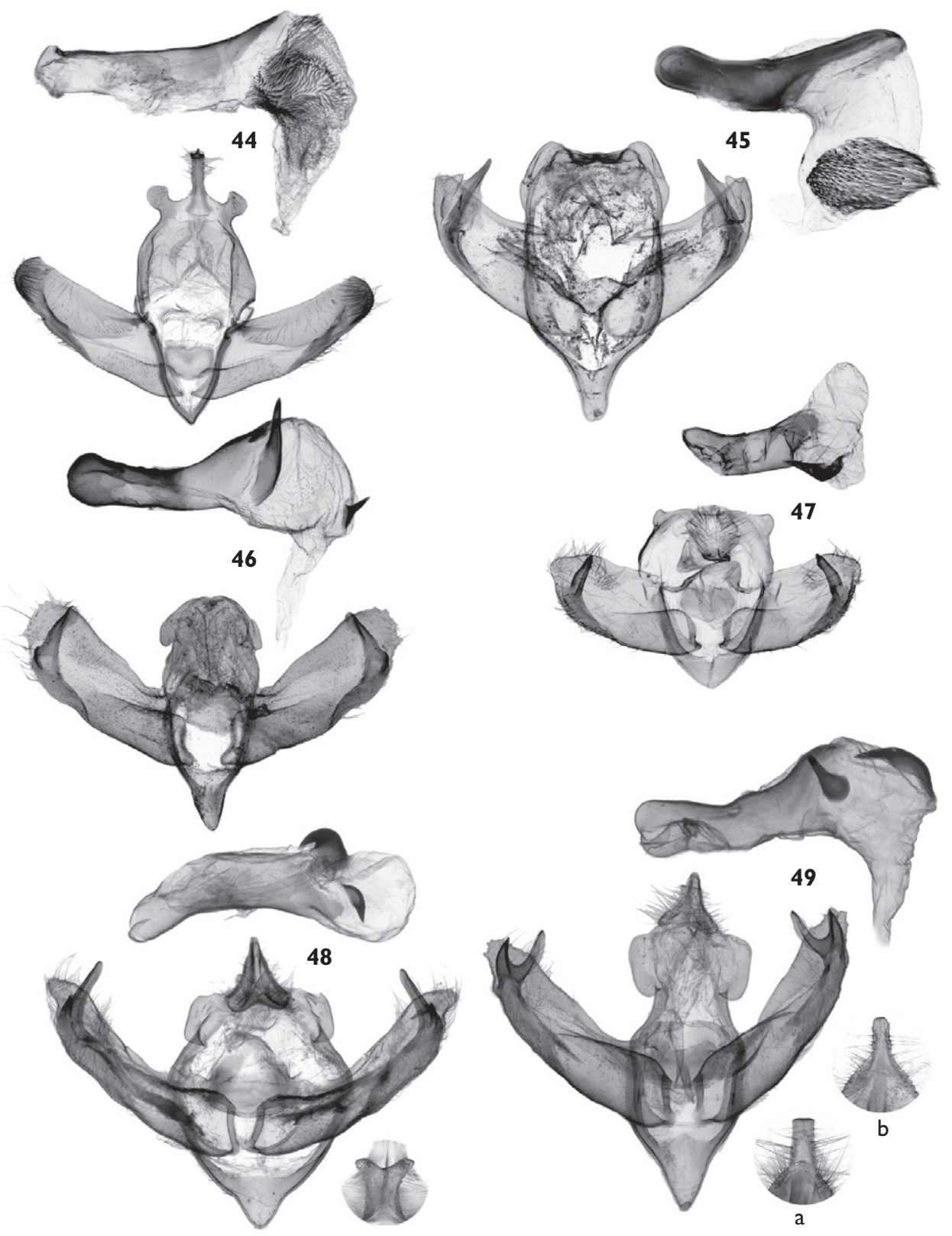

Figures 44-49. Panthea male genitalia

44. Lichnoptera decora, Queretero, MEX; 45. P. apanthea, El Paso Co., CO., USA; 46. P. judyae Grant Co., NM, USA; 47. P. reducta, Pedemales, DR; 48. P. gigantea, El Dorado Co., CA., USA, a. tip of uncus; 49. P. guatemala, Oaxaca MEX., a. tip of uncus, Oaxaca, b. tip of uncus, Chiapas, MEX. 


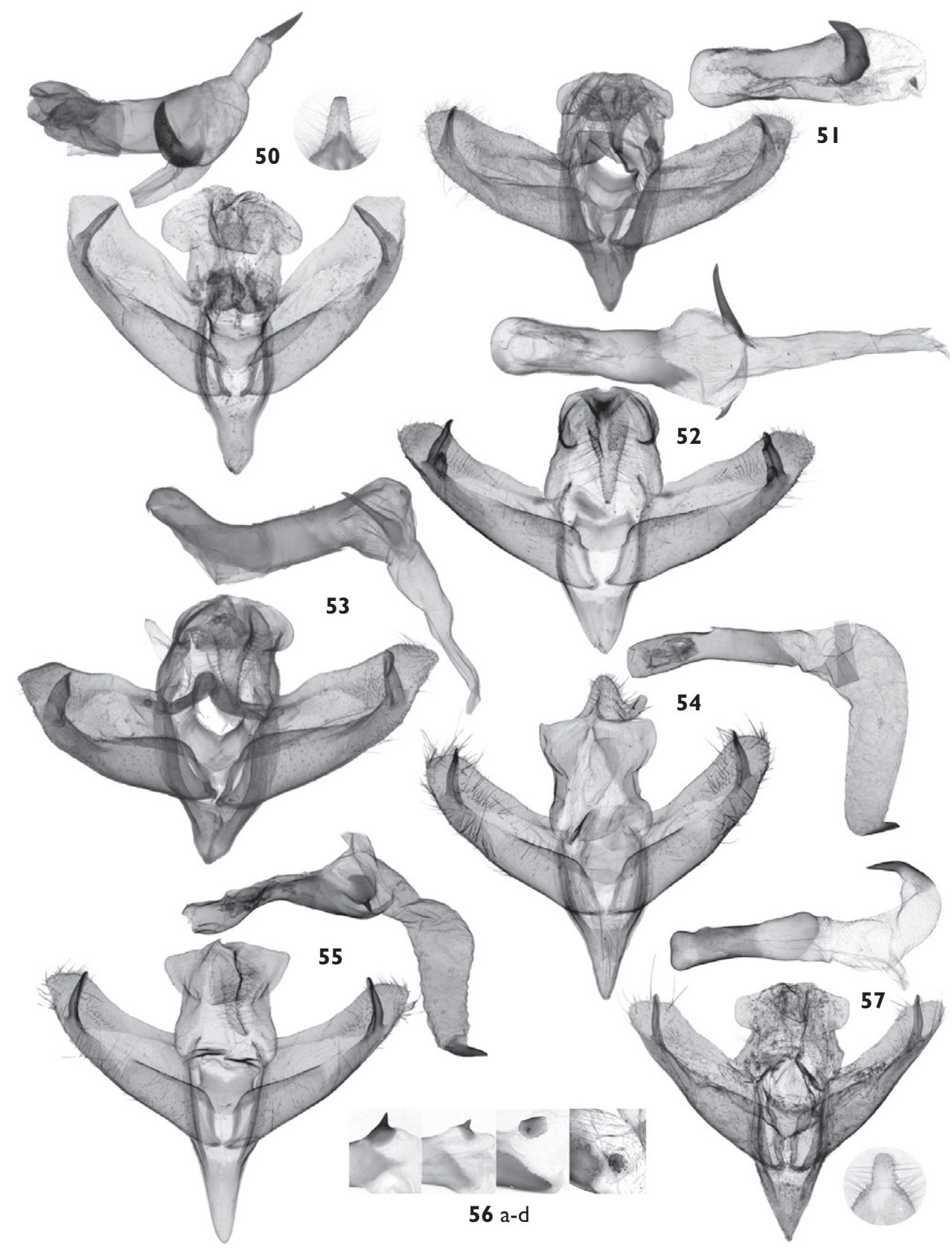

Figures 50-57. Panthea male genitalia

50. P. virginarius, Josephine Co. OR., USA; 5 I. P. virginarius Wyoming variant, Lincoln Co., WY., USA; 52. $P$. acronyctoides nigra, Albany Co., WY, USA; 53. $P$. a. acronyctoides, Steuben, ME, USA; 54. P. furcilla furcilla, Norfolk Co., MA., USA; 55. P. furcilla australis, Whitfield Co., GA. USA; 56. Panthea f. furcilla -f. australis intermediate specimens, showing variation in size of basal cornuti; a. P.G. Co., MD; b, c. Owsley Co., KY; d. Elko Co., PA. 57. P. greyi. Coconino Co., AZ, USA. 

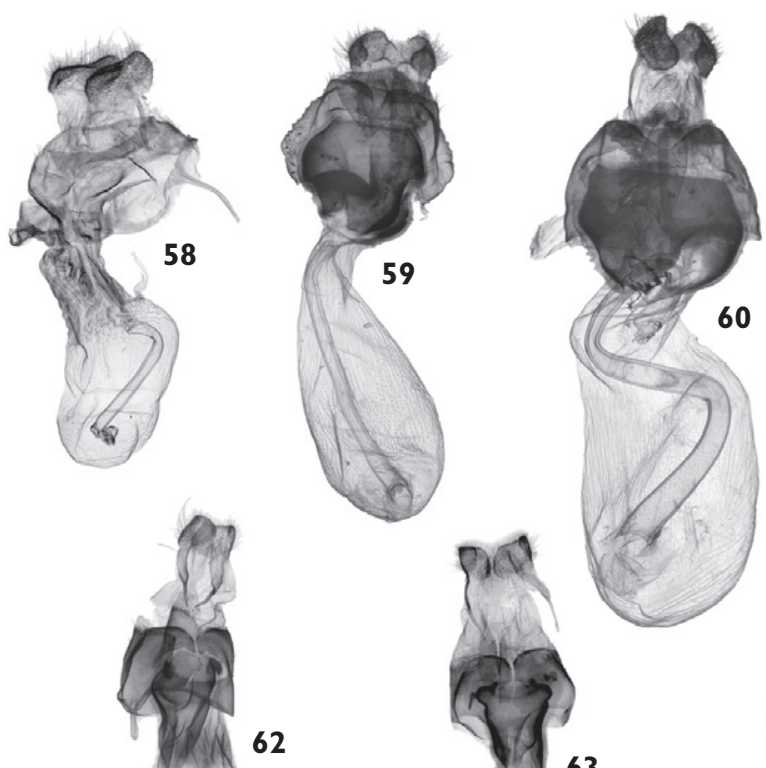

62

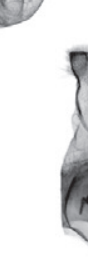

63

66
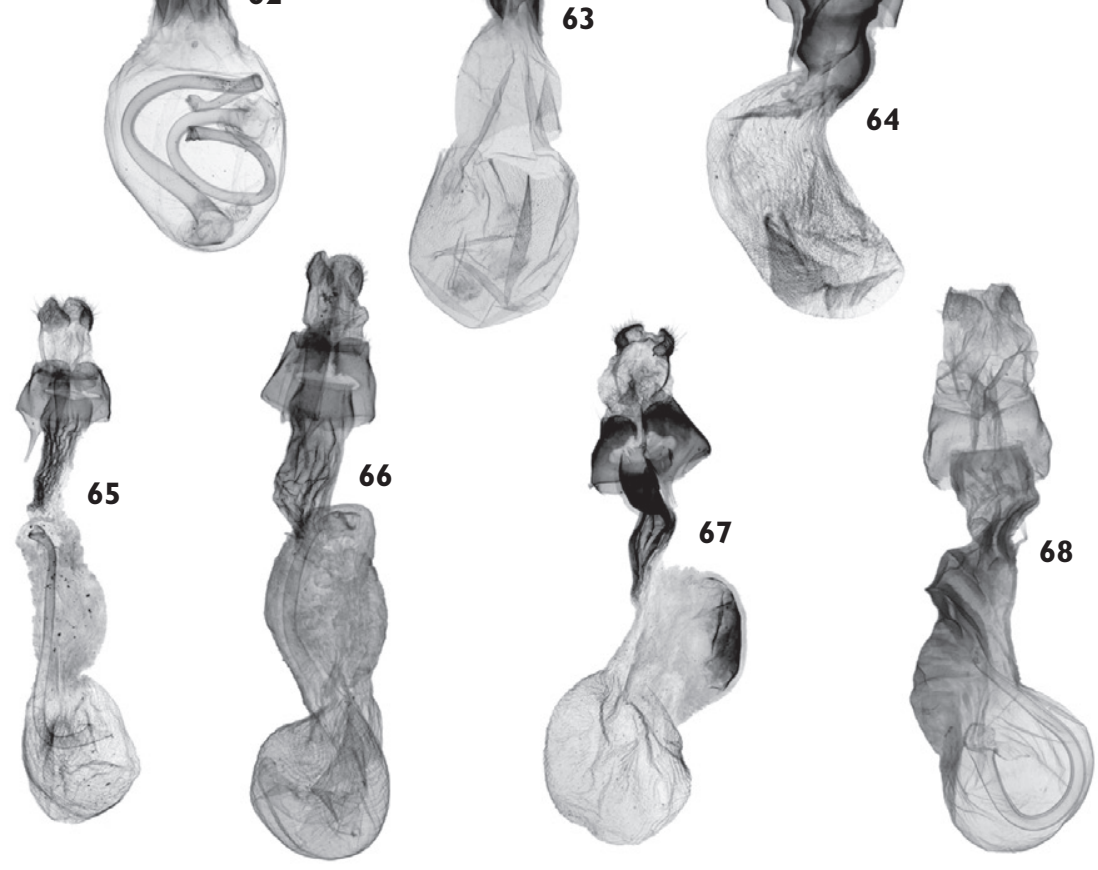

Figures 58-68. Panthea female genitalia

58. P. apanthea, Coconino Co, AZ. USA; 59. P. judyae, Chihuahua, MEX; 60. P. gigantea, Chihuahua, MEX; 6 I. P. guatemala, Oaxaca, MEX; 62. P. virginarius, Missoula Co., MT., USA; 63. P. acronyctoides nigra, Teller Co., CO., USA; . 64. P. a. acronyctoides, Ashland Co., WI, USA; 65. P. f. furcilla, Windham Co., CT, USA; 66. P. f. furcilla-f. nigra intermediate, Dauphin Co., PA., USA; 67. P. furcilla australis, Whitfield Co., GA, USA; 68. Panthea greyi, Apache Co., AZ., USA. 


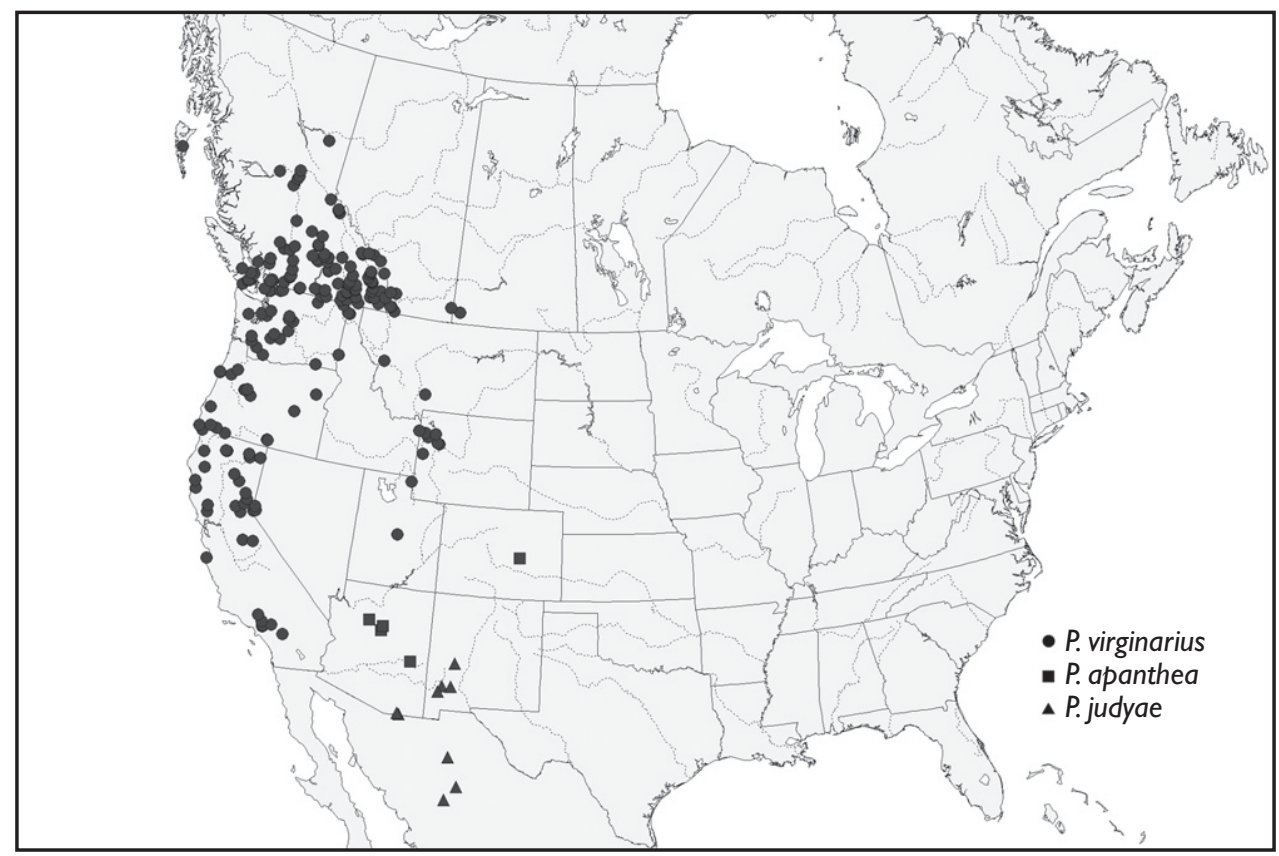

Fig. 69. Distribution of examined specimens of P. virginarius, $P$. apanthea and $P$. judyae.

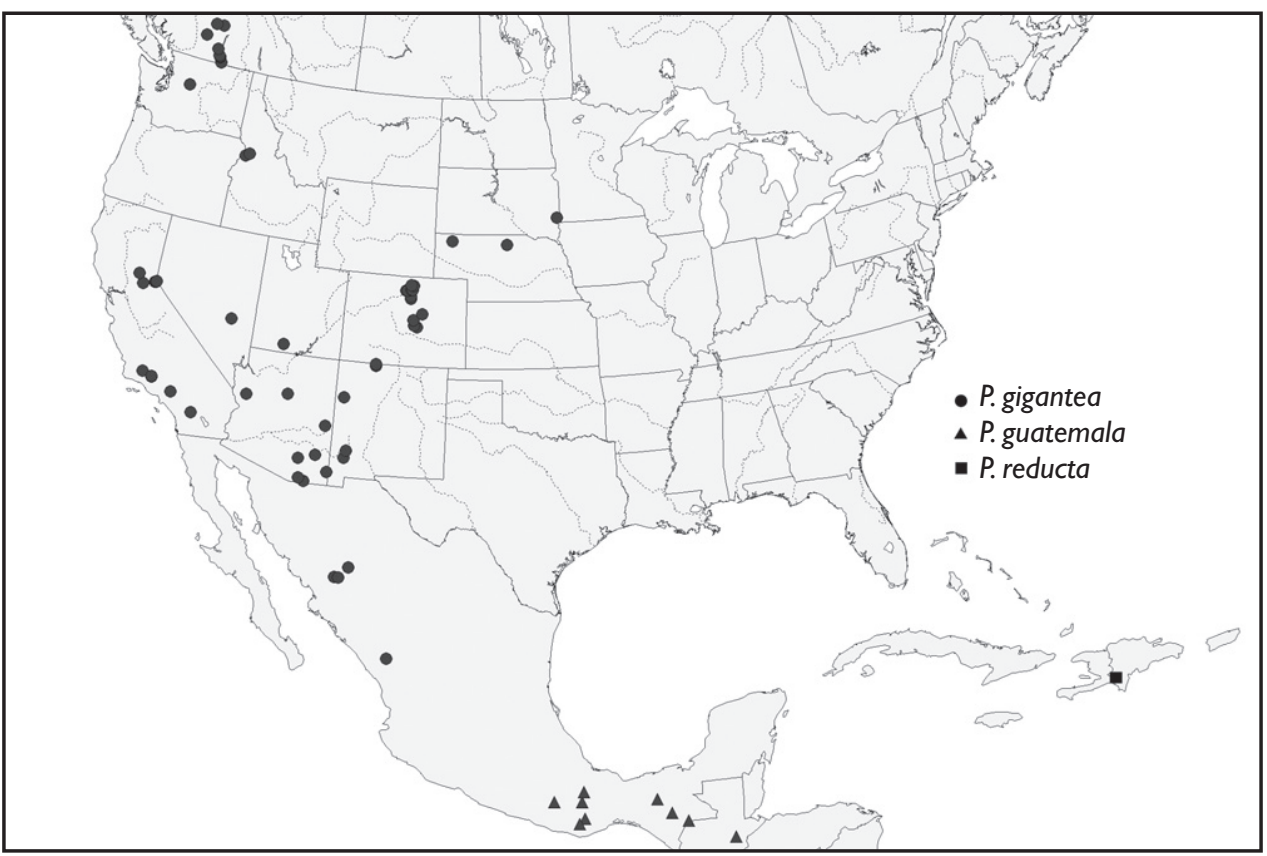

Fig. 70. Distribution of examined specimens of $P$. gigantea, $P$. guatemala, and $P$. reducta. 


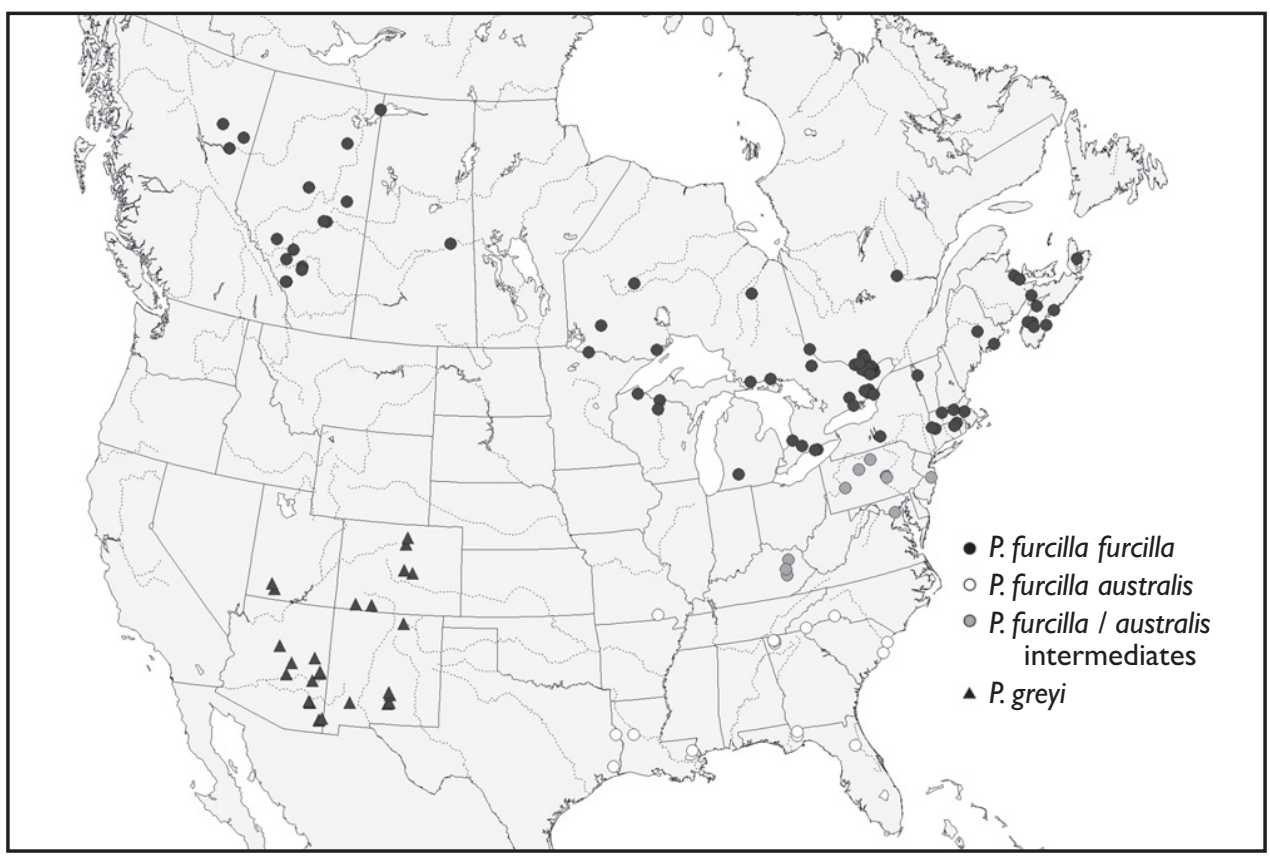

Fig. 7 I. Distribution of examined specimens of $P$. furcilla and $P$. greyi.

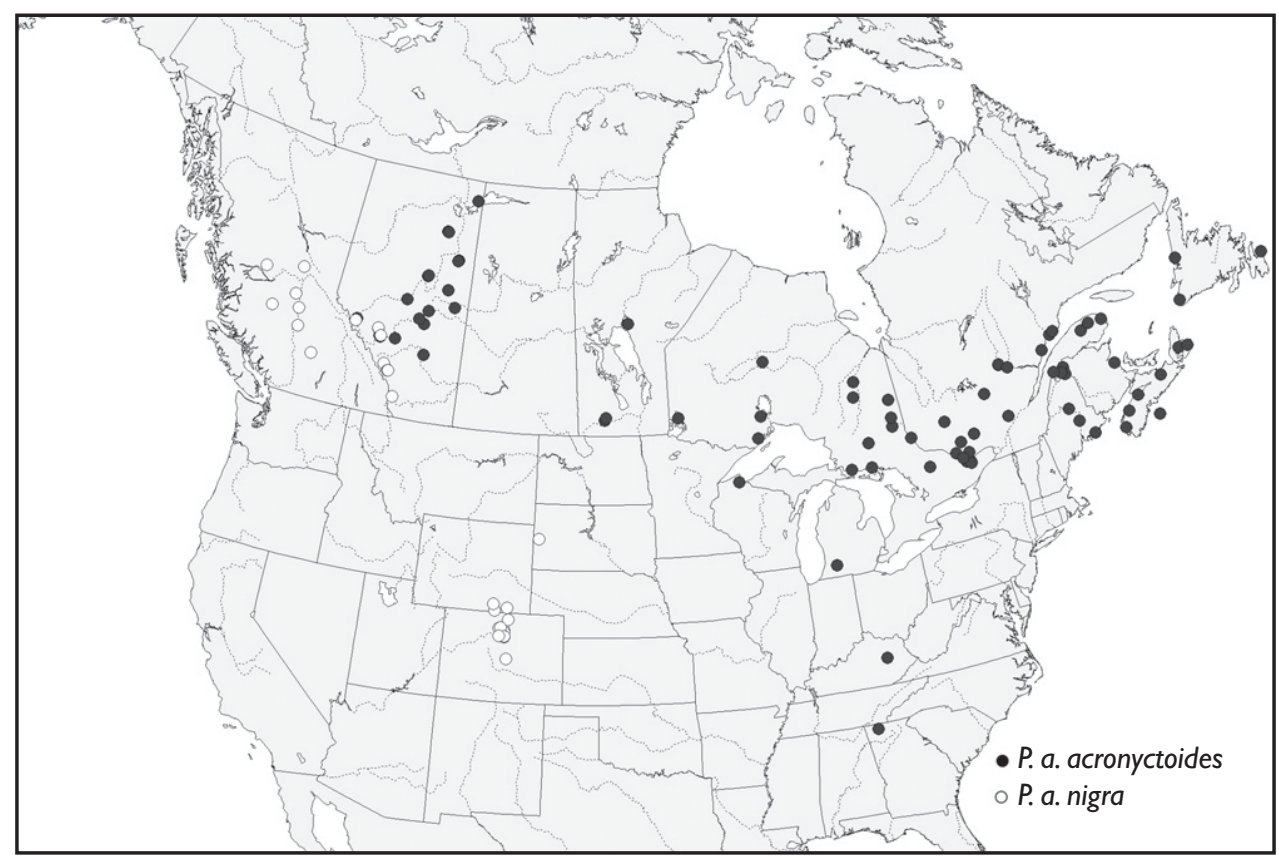

Fig. 72. Distribution of examined specimens of $P$. acronyctoides. 